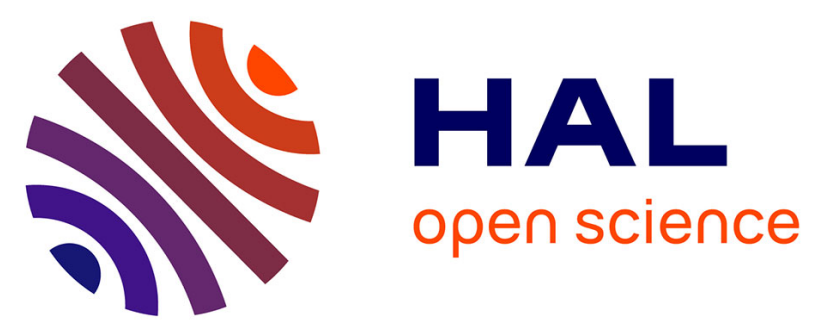

\title{
A simulation method to infer tree allometry and forest structure from airborne laser scanning and forest inventories
}

Fabian Jörg Fischer, Fabian Jörg Fischer, Nicolas Labrière, Grégoire Vincent, Bruno Hérault, Alfonso Alonso, Hervé Memiaghe, Pulchérie Bissiengou, David Kenfack, Sassan Saatchi, et al.

\section{To cite this version:}

Fabian Jörg Fischer, Fabian Jörg Fischer, Nicolas Labrière, Grégoire Vincent, Bruno Hérault, et al.. A simulation method to infer tree allometry and forest structure from airborne laser scanning and forest inventories. Remote Sensing of Environment, 2020, 251, pp.112056. 10.1016/j.rse.2020.112056 . hal03005989

\section{HAL Id: hal-03005989 \\ https://hal.science/hal-03005989}

Submitted on 5 Dec 2020

HAL is a multi-disciplinary open access archive for the deposit and dissemination of scientific research documents, whether they are published or not. The documents may come from teaching and research institutions in France or abroad, or from public or private research centers.
L'archive ouverte pluridisciplinaire HAL, est destinée au dépôt et à la diffusion de documents scientifiques de niveau recherche, publiés ou non, émanant des établissements d'enseignement et de recherche français ou étrangers, des laboratoires publics ou privés. 


\section{A simulation method to infer tree allometry and}

\section{2 forest structure from airborne laser scanning}

\section{3 and forest inventories}

4 Fabian Jörg Fischera, *, Nicolas Labrièrea , Grégoire Vincent ${ }^{\mathrm{b}}$, Bruno Héraultc,d,

5 Alfonso Alonso ${ }^{\text {, }}$, Hervé Memiaghef, Pulchérie Bissiengoug, David Kenfack ${ }^{\text {h }}$, Sassan

6 Saatchii, and Jérôme Chave ${ }^{a}$

7 a Laboratoire Évolution et Diversité Biologique, UMR 5174 (CNRS/IRD/UPS), 118

$8 \quad$ Route de Narbonne, 31062 Toulouse Cedex 9, France

9 b AMAP, Univ Montpellier, IRD, CIRAD, CNRS, INRAE, Montpellier, France

10 c Cirad, Univ Montpellier, UR Forests \& Societies, F-34000 Montpellier, France.

$11 \mathrm{~d}$ INPHB, Institut National Polytechnique Félix Houphouët-Boigny, Yamoussoukro,

12 Ivory Coast

13 e Center for Conservation and Sustainability, Smithsonian Conservation Biology

14 Institute, 1100 Jefferson Drive SW, Suite 3123, Washington DC 20560-0705, USA

15 f Institut de Recherche en Écologie Tropicale (IRET), Centre National de la Recherche

16 Scientifique et Technologique (CENAREST), B.P. 13354, Libreville, Gabon

17 g Institut de Pharmacopée et de Médecine Traditionnelles (IPHAMETRA)/Herbier

18 National du Gabon, Centre National de la Recherche Scientifique et Technologique

19 (CENAREST), B.P. 1165, Libreville, Gabon

20 h Center for Tropical Forest Science -Forest Global Earth Observatory, Smithsonian

21 Tropical Research Institute, West Loading Dock, 10th and Constitution Ave NW,

22 Washington DC 20560, USA 
23 i Jet Propulsion Laboratory, California Institute of Technology, 4800 Oak Grove Drive, $24 \quad$ Pasadena, CA 91109, USA

25

$26 *$ Correspondence: fabian.j.d.fischer@gmx.de

27 Keywords: vegetation structure; tropical forest; individual-based modeling; airborne 28 lidar; approximate bayesian computation; allometry; biomass; canopy space filling 29 
Tropical forests are characterized by large carbon stocks and high biodiversity, but they are increasingly threatened by human activities. Since structure strongly influences the functioning and resilience of forest communities and ecosystems, it is important to quantify it at fine spatial scales.

Here, we propose a new simulation-based approach, the "Canopy Constructor", with which we quantified forest structure and biomass at two tropical forest sites, one in French Guiana, the other in Gabon. In a first step, the Canopy Constructor combines field inventories and airborne lidar scans to create virtual 3D representations of forest canopies that best fit the data. From those, it infers the forests' structure, including crown packing densities and allometric scaling relationships between tree dimensions. In a second step, the results of the first step are extrapolated to create virtual tree inventories over the whole lidar-scanned area.

Across the French Guiana and Gabon plots, we reconstructed empirical canopies with a mean absolute error of 3.98m [95\% credibility interval: $3.02,4.98$ ], or $14.4 \%$, and a small upwards bias of $0.66 \mathrm{~m}[-0.41,1.8]$, or $2.7 \%$. Height-stem diameter allometries were inferred with more precision than crown-stem diameter allometries, with generally larger heights at the Amazonian than the African site, but similar crown-stem diameter allometries. Plot-based aboveground biomass was inferred to be larger in

50 French Guiana with $400.8 \mathrm{t} \mathrm{ha}^{-1}$ [366.2 - 437.9], compared to $302.2 \mathrm{t}$ ha-1 in Gabon 51 [267.8 - 336.8] and decreased to $299.8 \mathrm{tha}^{-1}[275.9-333.9]$ and $251.8 \mathrm{t} \mathrm{ha}^{-1}$ [206.7 291.7] at the landscape scale, respectively. Predictive accuracy of the extrapolation procedure had an RMSE of $53.7 \mathrm{t} \mathrm{ha}^{-1}(14.9 \%)$ at the 1 ha scale and $87.6 \mathrm{tha}^{-1}(24.2 \%)$ at 
54 the 0.25 ha scale, with a bias of $-17.1 \mathrm{t} \mathrm{ha}^{-1}(-4.7 \%)$. This accuracy was similar to regression-based approaches, but the Canopy Constructor improved the representation

56 of natural heterogeneity considerably, with its range of biomass estimates larger by

$5754 \%$ than regression-based estimates.

58

59 The Canopy Constructor is a comprehensive inference procedure that provides fine-

60 scale and individual-based reconstructions even in dense tropical forests. It may thus

61 prove vital in the assessment and monitoring of those forests, and has the potential for a

62 wider applicability, for example in the exploration of ecological and physiological

63 relationships in space or the initialisation and calibration of forest growth models. 


\section{Introduction}

65 Tropical forests store more than half of terrestrial living biomass (Pan et al., 2011) and shelter a disproportionate share of terrestrial biodiversity. Yet they are increasingly threatened by human activities, from agricultural encroachment and fragmentation to global climate change (Lewis et al., 2015). Tropical forests thus play a pivotal role in carbon mitigation and conservation strategies such as natural regeneration and the avoidance of deforestation (Chazdon et al., 2016; Grassi et al., 2017). To prioritize such strategies and assess their efficacy, methods are needed that accurately quantify forest structure, i.e. the vertical and horizontal arrangement of tree stems and crowns. Forest structure shapes ecosystem functioning (Shugart et al., 2010), wood quality (Van Leeuwen et al., 2011), microclimates and habitats (Davis et al., 2019), and the resilience and resistance of ecosystems to disturbances (DeRose and Long, 2014; Seidl et al., 2014; Tanskanen et al., 2005). Forest structure also varies across climates (Pan et al., 2013) and across successional states and environmental conditions (Lutz et al., 2013). Approaches to quantify forest structure should therefore be able to account for local heterogeneities and be applicable over large areas (R. Fischer et al., 2019). Field-based inventories provide detailed descriptions of diameter distributions across time and space and form the bedrock of research in forest ecology. However, the mapping, measuring and identification of trees is typically limited to a few hectares.

83 Furthermore, it is usually difficult to obtain reliable measurements of tree height and other crown dimensions from the ground (Sullivan et al., 2018). As a result, it has long been a challenge to correctly describe the three-dimensional stratification of forests (Oldeman, 1974). 

obtain data in three dimensions (Atkins et al., 2018; Disney, 2019). At regional scales, airborne laser scanning (ALS), i.e. aircraft-mounted laser scanning devices, are now commonly used to survey forest stratification over thousands of hectares. The data can be used to infer canopy height and leaf density at sub-meter resolution (Riaño et al., 2004; Rosette et al., 2008; Vincent et al., 2017), with diverse purposes, from estimating carbon stocks (Asner and Mascaro, 2014) to mapping animal habitats (Goetz et al., 2010). In some situations, even individual tree dimensions - especially tree height, crown area and depth - can be deduced by segmenting dense ALS point clouds into individual plants and their components (Aubry-Kientz et al., 2019; Ferraz et al., 2016; Hyyppä and Inkinen, 1999; Morsdorf et al., 2004). In particular for emergent and more loosely spaced trees, full crowns are often visible in ALS datasets and can be monitored from above (Levick and Asner, 2013; Meyer et al., 2018; Stovall et al., 2019). While this technique has been well-researched in temperate and boreal forests, its implementation

101 is more difficult in the multistoried forests typically found in the tropics. In the latter case, many trees are overtopped and difficult to delineate, so a large part of the information on individual tree size is inaccessible. Furthermore, even when tree crowns have been isolated, the matching of crowns to ground-measured diameters is made difficult by asymmetries in tree growth and uncertainties in geo-positioning. Here we propose an alternative, simulation-based strategy to infer forest structure. It relies on a combination of ALS data and field inventories to first reconstruct 108 forests in 3D on local field plots, and then uses local summary statistics to create virtual 109 tree inventories over the whole ALS-extent. We call our method the "Canopy 110 Constructor". It is inspired by the fusion of forest simulators with lidar data (Fassnacht 111 et al., 2018; F. J. Fischer et al., 2019; Hurtt et al., 2004; Knapp et al., 2018; Shugart et al., 
2015), space-filling algorithms (Bohn and Huth, 2017; Farrior et al., 2016; Taubert et al., 2015) and the use of synthetic forests to link lidar and ground inventories (Palace et al., 2015; Spriggs et al., 2015). The Canopy Constructor brings these approaches together to

115 provide a comprehensive picture of forest canopies in space, with applications in

116 biomass mapping, the study of remote sensing techniques and the initialization or 117 calibration of forest growth models (F. J. Fischer et al., 2019). based forest growth model TROLL (Maréchaux and Chave 2017) and notions from

To implement it, we used the assumptions of the spatially explicit and individualallometric scaling theories, i.e. that tree dimensions can be predicted through allometric relationships (Niklas 2007) and that space-filling concepts translate between the properties of individual trees and those of the whole stand (Niklas et al., 2003; West et al., 2009). Unlike general theories of allometric scaling, however, the Canopy Constructor seeks to infer realized scaling relationships from local plot data, and then uses these to predict tree positions and dimensions in space.

Here, we describe the Canopy Constructor algorithm, and apply it at two tropical rain forest sites, one in French Guiana (Chave et al., 2008a), one in Gabon (Memiaghe et al., 2016), to infer the allometric relationships between trunk diameter and crown dimensions, and to create virtual tree inventories across several thousands of hectares, from which fine-scale above-ground biomass maps can be deduced. Specifically, we asked the following questions: (i) How well can we reproduce 3D scenes of tropical forests from relatively simple principles, (ii) Are tree inventories and ALS data sufficient to infer allometric scaling relationships between tree dimensions, and how do these relationships differ between sites? (iii) What is the biomass density at both sites and how is it distributed across the landscape? (iv) How accurate is the Canopy Constructor approach in extrapolation and does it have an advantage over conventional biomass 
137 mapping methods? We evaluated the Canopy Constructor's predictions through

138 independent data and cross-validation, compared the accuracy against regression-based

139 approaches, and, for practical purposes, provide an assessment of its accuracy with a

140 reduced set of simulations. 


\section{Materials and Methods}

\section{$142 \quad 2.1$ Study sites}

143 To answer our research questions, we selected two tropical sites, one in French Guiana,

144 and one in Gabon. The two sites were chosen based on their location in the Earth's two

145 largest tropical forest biomes, with high biomass and biodiversity, which makes it a

146 challenge to correctly estimate their structure. Furthermore, their biomass has been

147 recently quantified, so we had empirical data sets and estimates at hand to compare our

148 approach with (Labriere et al., 2018). Throughout, we refer to them as study sites, while 149 tree inventories are referred to as plots.

The French Guiana site is the Nouragues Ecological Research Station $\left(4.06^{\circ} \mathrm{N}\right.$,

$15152.68^{\circ} \mathrm{W}$ ). The site is characterised by a lowland tropical rainforest (except for a granitic

152 outcrop at $430 \mathrm{~m}$ asl), ca. $2900 \mathrm{~mm} \mathrm{yr}^{-1}$ rainfall, a 3-month dry season in September-

153 November, and a shorter one in March. Its forest forms part of the Guiana Shield, at the

154 northeastern tip of Amazonia, a region with high tree wood densities and biomass, and a

155 large fraction of legume species (ter Steege et al., 2006). Tree inventories have been

156 carried out since 1992, including a 10-ha plot called "Grand Plateau" and a 12-ha plot

157 called "Petit Plateau" (Chave et al., 2008b). Trees with diameters $\geq 10 \mathrm{~cm}$ at $1.30 \mathrm{~m}$

158 above the ground (diameter at breast height, $\mathrm{dbh}$ ) or above deformities and buttresses

159 are mapped, tagged and identified at species level when possible. The two plots differ in

160 their disturbance regime and canopy structure (cf. Figure S1 for their canopy height

161 models), but a typical hectare includes between 500 and 600 trees $\geq 10 \mathrm{~cm} \mathrm{dbh}$ and $\geq$

162150 tree species. Dominant species are Eschweilera coriacea, Quararibea duckei, Lecythis

163 persistens, Vouacapoua americana, Eperua falcata and the palm Astrocaryum sciophilum

164 (Poncy et al., 2001). Several ALS surveys have been conducted since 2008 (Réjou-

165 Méchain et al., 2015), with a Riegl lidar (LMS-Q560) mounted on a fixed-wing aircraft. 
166 We here used the 2012 tree inventory and ALS dataset which covers 2,400 ha at a pulse 167 density of $\sim 12$ per $\mathrm{m}^{2}$ (based on density of last returns) and an overall point density of

168 18 per $\mathrm{m}^{2}$ (all returns; Réjou-Méchain et al., 2015).

The second site, Rabi, is located in southwestern Gabon's Gamba Complex,

$170\left(1.92^{\circ} \mathrm{S}, 9.88^{\circ} \mathrm{E}\right)$. The site is characterized by annual rainfall of ca. $1970 \mathrm{~mm} \mathrm{yr}^{-1}$

171 (Anderson-Teixeira et al., 2015a), and is covered with a lowland old-growth tropical rain

172 forest, with local human disturbances by oil operations and selective logging. A 25 ha

173 plot has been censused twice, including all trees $\geq 1 \mathrm{~cm} \mathrm{dbh}$, in 2010-2012 and 2016-

1742017 (Memiaghe et al., 2016), following the ForestGEO protocol (Condit, 1998). The plot

175 has an estimated 84 species ha-1 and 447 trees $\geq 10 \mathrm{~cm} \mathrm{dbh} \mathrm{ha}^{-1}$ (Memiaghe et al., 2016).

176 The legume family contributes a large fraction of species, trees and biomass, with four

177 species, Tetraberlinia moreliana, Tetraberlinia bifoliolata, Gilbertiodendron ogoouense, 178 and Amanoa strobilaceae, accounting for ca. 45\% of canopy tree species (Engone Obiang 179 et al., 2019). An airborne lidar campaign over 900 ha was carried in 2015, using a

180 helicopter-based RIEGL VQ-480i, with pulse densities of $\sim 2.5$ per $\mathrm{m}^{2}$, and the plot is part 181 of the AfriSAR campaign (Fatoyinbo et al., 2017).

\subsection{The Canopy Constructor algorithm}

184 The Canopy Constructor algorithm consists of two steps. In a first step, the 3D-forest 185 structure is reconstructed over a local plot ("calibration plot"), relying on a tree 186 inventory, a co-registered ALS-scan and stand-average allometric relationships that 187 relate trunk diameter, tree height and crown radius. After an initial, random 188 reconstruction, tree properties are swapped until a high degree of similarity between 189 the empirical, ALS-derived canopy and the simulated canopy is achieved, but without 190 altering the underlying allometric structure. If allometric parameters are not known 
empirically, they are inferred through Bayesian inversion where the routine is run with a wide range of parameters (see e.g., Hartig et al., 2011). At the end this step, several

193 best-fit 3D scenes are obtained, representing the most likely structural configurations

194 and allometric scaling relationships on the calibration plot. match those of the calibration plot. In the following, we describe both steps in detail.

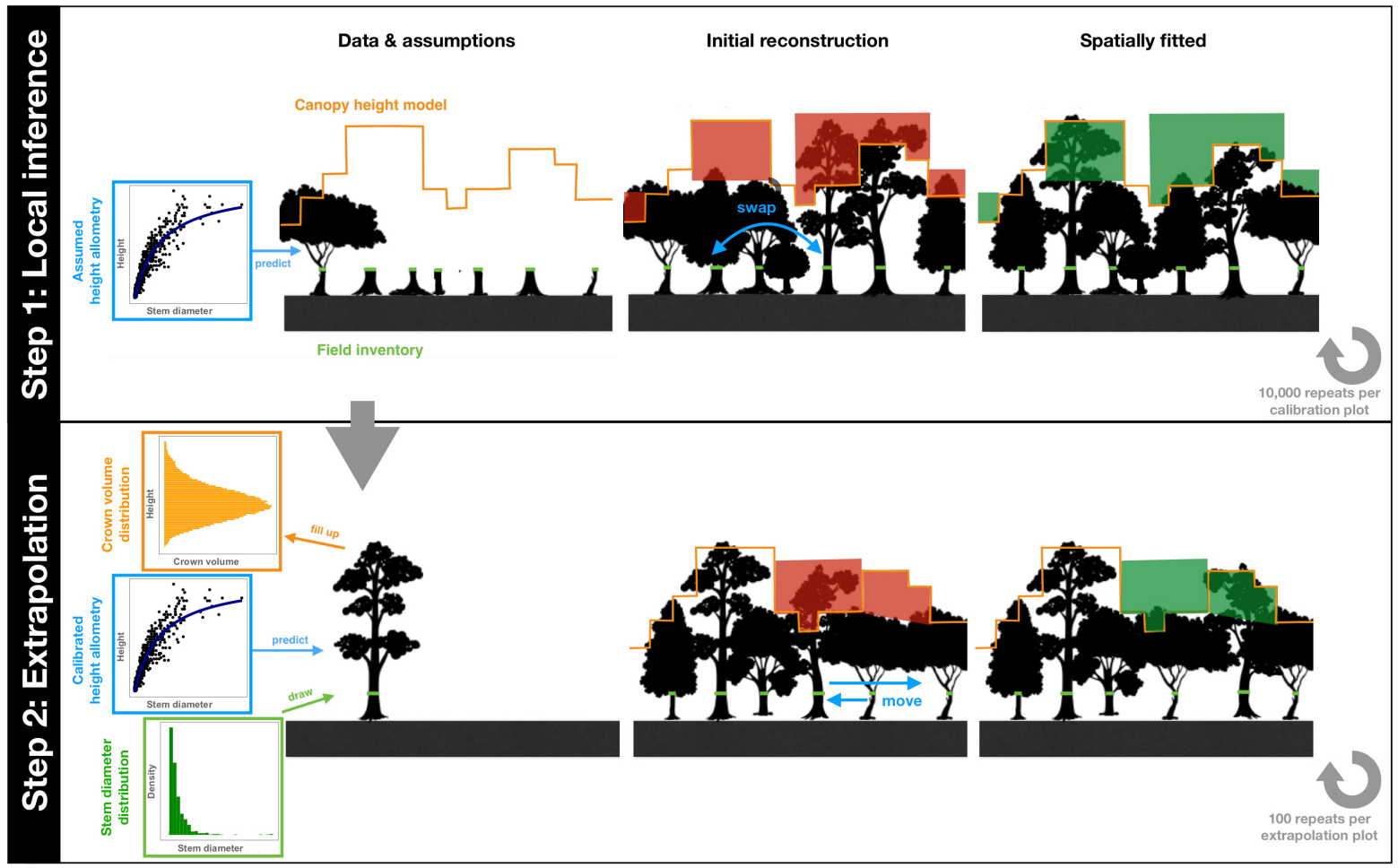

200 Figure 1: The two-step procedure of the Canopy Constructor algorithm. Step 1 uses tree inventory data, and a canopy height model (CHM). To infer the position and size of each tree, the algorithm creates an initial reconstruction drawing randomly dimensions from allometric relationships between tree dimensions. In ill-fitting regions (red), deviations from the allometric means are swapped between trees

204 until a good spatial fit is obtained (green). Step 2 extrapolates the results of step 1 and creates virtual 205 inventories across thousands of hectares, following the same fitting algorithm as in step 1, but with fitted trees drawn from a distribution (see main text for details). 
208 (https://github.com/fischer-fjd/CanopyConstructor). Statistical analysis and

209 visualization were carried out in R (R Development Core Team, 2019) with the packages

210 data.table, raster, ggplot2, and viridis (Dowle and Srinivasan, 2018; Garnier, 2018;

211 Hijmans, 2016; Wickham, 2011) and their dependencies.

212

\subsubsection{Forest structure inference and model calibration}

214 The Canopy Constructor inputs tree diameters and locations from a forest inventory, 215 predicts tree heights and crown diameters from allometric scaling and fills up an initial

$2163 \mathrm{D}$-canopy for the fitting procedure (resolution of $1 \mathrm{~m}^{3}$ ), as in the TROLL model

217 (Maréchaux and Chave, 2017). To summarize canopy structure, we chose the canopy

218 height model (CHM), defined as the top-of-canopy height above ground for a given grid 219 cell (here at $1 \mathrm{~m}^{2}$ resolution). For the tree-by-tree reconstruction, the minimal trunk 220 diameter size was set to $1 \mathrm{~cm}$. Each surveyed tree was assigned to a grid with $1 \mathrm{~m}^{2}$ cell 221 size. If several trees co-occured on the same cell, their positions were slightly jittered to 222 fill up adjacent cells. For multistemmed trees, a single effective stem dbh was retained,

223 equal to $d b h_{e f f}=\sqrt{\sum_{i} d b h_{i}^{2}}$. For simplicity, we refer to $d b h_{e f f}$ as $d b h$. For tree

224 inventories with a higher cutoff than $1 \mathrm{~cm}\left(\right.$ e.g. $d b h_{\text {cutoff }}=10 \mathrm{~cm}$ or $\left.30 \mathrm{~cm}\right)$, power-law and 225 exponential dbh-size distributions were assumed to fill up and randomly place trees < $226 d b h_{\text {cutoff }}$ (Taubert et al., 2015, Farrior et al., 2018).

\section{Allometric relationships}

229 To predict canopy structure from the field-measured stems, the Canopy Constructor 230 assumes the following allometric models: 


$$
h=\frac{h \max \times d b h}{\left(a_{h}+d b h\right)} \times \exp \left(\varepsilon_{h}\right)
$$

231 and

$$
c r=\exp \left(a_{c r}+\varepsilon_{c r}\right) \times d b h^{b_{c r}}
$$

232 In Equation (1), $h$ is total tree height, $d b h$ diameter at breast height, while $h m a x$ and $a_{h}$

233 are Michaelis Menten coefficients interpreted as the asymptotic height that trees reach

234 at large trunk diameter values and the approximately linear slope of the increase of

235 height with diameter at small trunk diameters, respectively. In Equation (2), $c r$ is the

236 tree's crown radius, and $a_{c r}$ and $b_{c r}$ are the intercept and slope of a log-log regression, i.e.

237 a power law model. Equation (1) was chosen instead of a power model to better capture

238 the saturating relationships typically found in tropical rain forests (Cano et al., 2019).

239 The $\varepsilon_{h}$ and $\varepsilon_{c r}$ are the respective error terms - i.e. the natural variation in allometry -,

240 given by:

$$
\varepsilon_{h} \sim N\left(0, \sigma_{h}\right)
$$

241 and

$$
\varepsilon_{c r} \sim N\left(0, \sigma_{c r}\right)
$$

242 The error terms generate a multiplicative error structure that accounts for the

243 heteroscedasticity in crown and height allometries (Molto et al., 2014). We assumed that

244 allometric variation did not depend on species identity, that $\varepsilon_{h}$ and $\varepsilon_{c r}$ were

245 independent, and that crown depth could be simply calculated as a proportion of $h$, as in 246 the TROLL model (Maréchaux and Chave, 2017).

To model crown shape more realistically, we defined the ratio $\gamma$ between the 248 radius at the top of the crown and its base, with a linear slope linking both layers. $\gamma$ 249 varies between 0 and 1: if $\gamma=0$, the tree crown is a cone, while if $\gamma=1$, it is a cylinder 250 (as in Maréchaux \& Chave, 2017). For the purposes of this study, we set $\gamma$ to 0.8 . This 
resulted in an improvement in the convergence of the crown fitting algorithm compared to simpler cylindrical shapes, better modelled the less clear-cut edges found empirically and accounted for the fact that real tree crowns are smaller than their cylindrical

254 envelopes.

Based on the crown shape parameter as well as a particular realization of the six

allometric parameters ( $\left.h m a x, a_{h}, a_{c r}, b_{c r}, \varepsilon_{h}, \varepsilon_{c r}\right)$, we created an initial 3D forest mockup, with deviations from allometric means randomly assigned to trees.

\section{Optimization algorithm}

260 The Canopy Constructor then optimizes the spatial overlap of the simulated and the 261 ALS-derived CHMs by readjusting trees and their crowns in space. To this effect, we 262 looped repeatedly through all trees on the grid, in random order, and applied one of 263 three operations described below. The loop was stopped when improvements in canopy

264 structure were marginal ( $<1 \%$ acceptance rates), usually achieved after 100-200

265 iterations. A similar algorithm was implemented in Taubert et al. (2015). For the majority of field-measured trees, we picked pairs of trees and swapped

267 their respective values of $\varepsilon_{h}$ (deviation in height) and $\varepsilon_{c r}$ (deviation in crown radius).

268 We then recalculated the new dimensions of both trees and kept the change if it resulted 269 in an increase in the overall goodness of fit between the simulated and ALS-derived 270 CHM. To keep the overall variance structure, trees were binned into logarithmic dbh 271 classes and only swapped when they were in the same dbh class. This procedure rapidly 272 redistributed deviations from the allometric means across the population of trees so as 273 to improve spatial fits, but preserved the initial allometric structure. 
their low numbers. Therefore, if there were less than 10 trees within a dbh bin across

277 the plot, we drew new tree sizes from equations (1) and (2). If the new draw resulted in

278 a better fit to empirical data, it was retained. To prevent bias in the allometric structure,

279 the expected crown radii and heights had to be preserved. We used a simple method,

280 allowing positive deviations from the mean only if the previous bin average deviated

281 negatively from the expected value, and vice versa.

282

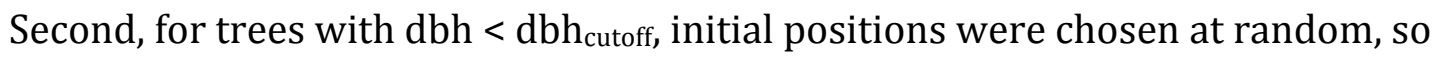

283 we did not change the trees' dimensions, but instead relocated the entire tree, within a

284 radius dependent on its height (but at least $10 \mathrm{~m}$ ). If the new location increased the

285 goodness of fit, the change was accepted. Few small trees were visible in the CHM, so

286 this procedure rarely modified the canopy, except in canopy gaps.

Plot boundaries bisect crown areas and may thus introduce errors in estimation procedures (Mascaro et al., 2011). To prevent biased estimates, we calculated the crown area outside the plot $C A_{i}^{\text {out }}$ and the total crown area $C A_{i}$ for each tree $i$, summed both

290 across all $\mathrm{n}$ trees per plot and computed the ratio $R=\frac{\sum_{i=1}^{n} C A_{i}^{\text {out }}}{\sum_{i=1}^{n} C A_{i}}$. During the optimization 291 procedure, we forced $R$ to remain approximately constant. If during the fitting process, $R$ exceeded its initial value, then the trial was accepted only if it lowered $R$, and vice versa. We further observed that the Canopy Constructor could assign large crowns to

294 lower canopy layers that barely affected the CHM and fit small crowns on the tallest 295 trees to mimick natural heterogeneity, a phenomenon similar to oversegmentation in 296 tree delineation approaches. To prevent this, we circled through all trees within a 297 distance $d i s t=C R_{\text {tree }}+C R_{\text {treemax }}$, for every newly fitted crown with $C R_{\text {tree }}$, and rejected 298 crown fittings that resulted in tree configurations where a large tree with a small crown 299 pierced a small tree with a large crown. 


\section{Goodness-of-fit metrics}

302 Each time a tree crown was updated, we tested whether this change increased the fit 303 with empirical values. To assess the goodness of the fit between virtual and empirical

304 CHMs, we used the mean of the absolute errors:

$$
M A E=\frac{1}{s_{\text {total }}} \sum_{s=1}^{s_{\text {total }}}\left|\operatorname{chm}_{\text {emp }}(s)-\operatorname{chm}_{\text {sim }}(s)\right|
$$

305 where each $s$ represents a $1 \mathrm{~m}^{2}$ grid cell of forest, $c h m_{e m p}$ the empirical canopy height of 306 that grid cell, $c h m_{\text {sim }}$ the simulated canopy height, derived from the highest non-empty voxel, and $s_{\text {total }}$ the total number of grid cells within the plot. MAE measures the matching of local canopy height patterns and was used instead of a mean squared error, because it is more robust with regard to outliers (Hill and Holland, 1977).

311 shrinkage towards the mean from an optimization of $M A E$ alone, we also used the 312 dissimilarity index of the canopy height distributions:

$$
D=\frac{1}{2} \sum_{h=0}^{h=h \max }\left|\mathrm{d}_{\mathrm{emp}}(h)-\mathrm{d}_{\mathrm{sim}}(h)\right|
$$

313 where $h$ is a discrete height index (in $\mathrm{m}$ ), and $\mathrm{d}_{\mathrm{emp}}$ and $\mathrm{d}_{\mathrm{sim}}$ are the densities of the

314 empirical and simulated height histograms across the surveyed area, i.e. total number of 315 canopy height occurrences, normalized by the number of $1 \mathrm{~m}^{2}$ grid cells. The factor $1 / 2$ 316 normalizes the metric to 1 and allows us to interpret it as a measure of distribution 317 overlap: the lower the dissimilarity, the higher the overlap. In the limit of $D=0$, both

318 distributions are identical, in the limit of $\mathrm{D}=1$, there is no overlap at all. Formally, if $O V L$

319 is the distribution overlap, then $D=1-O V L$, with $O V L=\sum_{h=0}^{h m a x} \min \left(d_{\text {emp }}(h), d_{\text {sim }}(h)\right)$

320 (Inman and Bradley, 1989; Swain and Ballard, 1991). 

acceptance rate was achieved for each $(<1 \%$ for trees $>10 \mathrm{~cm} \mathrm{dbh}$, typically reached within 50 iterations for the $M A E$, and within 5 iterations for the dissimilarity). We then

324 used the difference between initial and final fits to normalize both metrics and

325 combined the normalized values to an overall error as follows:

$$
\delta=\sqrt{M A E_{\text {norm }}^{2}+D_{\text {norm }}^{2}}
$$

326 In a final number of iterations, we minimized $\delta$. The combined metric ensured that

327 crowns did not only fit spatially at local scales, encapsulated by a low $M A E$, but also

328 preserved the overall canopy height model distribution, as measured by $D$.

\section{Inferring Allometric Parameters by Approximate Bayesian Computation}

331 The optimization algorithm finds the best canopy reconstruction, given a set of

332 allometric parameters. However, allometric parameters are rarely known, so we used an

333 Approximate Bayesian Computation rejection scheme (Csilléry et al., 2010; Hartig et al.,

334 2014; F. J. Fischer et al., 2019) to infer them. The prior probability distribution of the six

335 allometric parameters, $\left(h \max , a_{h}, a_{c r}, b_{c r}\right)$ and $\left(\sigma_{h}, \sigma_{c r}\right)$ was approximated by 10,000

336 random draws. We applied the Canopy Constructor to the allometric parameter

337 combinations, and retained only the best $1 \%$ of canopy reconstructions (Csilléry et al.,

338 2010). The retained parameter values were used to generate a posterior probability

339 distribution over credible allometric parameterizations given the data.

We chose flat parameter priors by drawing from uniform distributions within

341 globally observed ranges of tree allometries (Jucker et al., 2017). Parameters were

342 drawn on logscales, except for the crown allometry intercept $a_{c r}$, drawn from a uniform

343 distribution on the back-transformed scale. A Latin hypercube scheme was employed to

344 minimize the computational burden, and correlation between allometric coefficients 
345

was accounted for using an algorithm of the R package 'pse' (Chalom et al., 2013), rewritten in $\mathrm{C}++$ for speed. Covariance coefficients were taken from the Jucker et al. data set (2017). Since crown depth did not influence canopy height - and thus did not directly affect the fitting procedure -, it was fixed to $20 \%$ of tree height throughout the procedure.

To assess goodness of fit, we again used the mean absolute error $(M A E)$ and dissimilarity $D$. But instead of normalizing by the within-simulation range, we normalized by the range across all simulations and combined the metrics to $\delta_{A B C}=$ $\sqrt{M A E_{\text {norm } A B C}^{2}+D_{\text {norm } A B C}^{2}}$

\subsubsection{Model extrapolation}

In step 2, the Canopy Constructor uses the local fit from step 1, extrapolates the trunk diameter probability distribution and allometric scaling relationships across the whole ALS-covered area and constructs virtual tree inventories from space-filling principles. We implemented the same fitting procedure as before, but since the location and size of stem diameters have to be inferred, now all trees are drawn from a distribution and then relocated to create better spatial fits.

\section{Space-filling principles}

As a measure of space-filling, we used the crown packing density $\varphi=\frac{1}{V_{\max }} \sum_{i} V_{i}$, where $V_{\max }$ is the maximally available volume within a section of the canopy, and $V_{i}$ the volume contribution of each tree to that section (Jucker et al., 2015; Taubert et al., 2015). The crown packing density is the ratio of unit crown volume to unit canopy volume $\left(\mathrm{m}^{3}\right.$ per $\mathrm{m}^{3}$ ). It can be calculated for single voxels, subsets of voxels or for the entire canopy. 
We defined the crown packing density at height $h$, with $0 \leq h \leq h_{\max }$, and with

$h_{\text {max }}$ top-of-canopy height, so that crown packing density was dependent on the

canopy's height. We then defined the following quantity: $\varphi\left(h, h_{\max }\right)$, the packing density

matrix, where columns represent top-of-canopy height $h_{\max }$ and rows represent within-

373 canopy height layers $h$ (cf. Figure S2, left panel). We set the size of height bins to $1 \mathrm{~m}$,

374 and their numbers ran from $0 \mathrm{~m}$ to maximum canopy height. On a per-voxel basis, each

375 tree's volume contribution to a voxel could thus be either 0 or $1 \mathrm{~m}^{3}$, but due to the

376 idealized crown shapes assumed in the Canopy Constructor, crown overlaps were more

377 frequent than in real forest stands, resulting in local packing densities $>1 \mathrm{~m}^{3}$.

\section{Inferring virtual inventories}

380 To infer virtual tree inventories across the whole ALS-covered area, we divided the lidar 381 scene into grid cells, roughly equivalent in size to the local field inventories. We then 382 used the CHM of each grid cell, combined it with the packing density matrix $\varphi$ obtained

383 from the 3D reconstructions of the local calibration plot and predicted crown volume 384 per height layer. This was achieved by calculating the ALS-derived canopy height distribution for each grid cell, denoted $\bar{c}_{A L S}$, and formalized as a vector of top-of-canopy height frequencies. Multiplying the ALS-derived canopy height vector with the packing

387 density matrix yielded the vector $\bar{v}_{A L S}=\boldsymbol{\varphi} \bar{c}_{A L S}$ (Figure S2). The quantity $\bar{v}_{A L S}$ is an estimate of total crown volume per height layer within the extrapolation cell. For grid cells that reached canopy heights larger than the calibration plot from which the packing

390 density matrix was derived, $\boldsymbol{\varphi}$ was calculated by averaging over the five non-empty

391 layers just beneath the missing layer.

Once the maximum space filling was determined, trees were drawn until a virtual

393 forest with a crown volume distribution $\bar{v}_{\text {virtual }}$ similar to $\bar{v}_{A L S}$ was obtained. We drew 
diameters from the calibration plot's probability distribution and used the previously inferred allometric relationships to predict tree height and crown radius. After randomly placing a tree on the grid, we updated $\bar{v}_{\text {virtual }}$ and determined by how much the new tree improved the fit with $\bar{v}_{A L S}$. To do so, we calculated the change in $\bar{v}_{\text {diff }}(h)=$ $\bar{v}_{A L S}(h)-\bar{v}_{\text {virtual }}(h)$ for every height layer $h$. If the crown volume in $h$ had not yet reached the reference value $\left(\bar{v}_{\text {diff }}(h)>0\right)$, every added unit of crown volume improved 400 the fit and was counted positively. As soon as the crown volume in the layer reached or exceeded the ALS-predicted volume $\left(\bar{v}_{\text {diff }}(h) \leq 0\right)$, every added crown volume unit

402 penalized the fit and was thus discounted. We then summed units of crown volume over 403 all layers $h$, and we accepted the tree if the overall balance was positive. Otherwise, the 404 tree was rejected. Each drawing cycle comprised $n$ draws, where $n$ is the number of 405 potential tree locations (i.e. the $\mathrm{m}^{2}$ area) under consideration. When the rejection rate 406 reached 100\% after a full cycle, we stopped the procedure. improved upon. This was done by displacing trees in relation to their height until an optimal spatial fit was achieved, as described for step 1. Again, we found that 100-200

410 iterations were sufficient to reach low rejection rates $(<1 \%)$. To propagate uncertainty, 411 the procedure was carried out for each of the 100 posterior reconstruction of the ABC 412 approach from step 1, with all grid cells collated to produce final maps.

\subsubsection{Application at the study sites}

415 At Nouragues, we used the geographically separated Petit Plateau (12 ha) and Grand 416 Plateau (10 ha). Applying the inference step on each of them individually allowed for a 417 comparison with previous studies and an assessment of within-site heterogeneity. We 418 also split the 25-ha plot at Rabi into two subplots (10-ha and 15-ha, respectively). We 
used plot sizes of $\geq 10$ ha because they minimized edge effects and kept a balance between the computational burden of the procedure and the sample sizes needed to swap random terms between crowns. On each subplot, we inferred forest structure (tree

422 dimensions, allometric parameters and crown packing densities). We then used the

423 larger plots at both sites (i.e. the 12 ha Petit Plateau and the 15 ha Rabi plot) to

424 extrapolate the virtual inventories across the whole landscape, subdivided into $400 \mathrm{~m} \mathrm{x}$ $425400 \mathrm{~m}$ grid cells (16 ha). Grid cells at the edges were discarded, and we created virtual 426 forest inventories over 2,016 ha at Nouragues and 832 ha at Rabi. To create the CHMs, lidar data were classified via TerraScan and then postprocessed with LAStools to obtain pit-free CHMs (Isenburg, 2018; Khosravipour et al., 2014). While the ALS data differed in point densities at the two sites (with considerably 430 lower densities at Rabi), the Canopy Constructor method was robust to such differences 431 because it was based on the CHM alone. Aboveground biomass (AGB) was estimated for 432 each tree $(\mathrm{kg})$, using the formula $A G B=0.0673 \times\left(\rho \times d b h^{2} \times h\right)^{0.976}$ (Chave et al., 2014), 433 where $\rho$ represents species-level wood density, obtained from a global database (Chave 434 et al., 2009; Zanne et al., 2009). For biomass mapping, tree biomass estimates were 435 aggreggated at 1 ha and 0.25 ha resolutions ( $\mathrm{t} \mathrm{ha}^{-1}$ ), a common grid size in biomass 436 mapping (Labrière et al., 2018; Réjou-Méchain et al., 2015). For consistency with 437 previous work, we computed AGB only for trees with $\mathrm{dbh} \geq 10 \mathrm{~cm}$. Diameter 438 measurement errors usually have small effects on plot-scale estimates (Réjou-Méchain et al., 2017), and since neither $\rho$ nor error in the AGB equation directly affected the 440 Canopy Constructor algorithm, we did not propagate error in these quantities. 


\subsection{Evaluation}

446 We assessed the accuracy of the Canopy Constructor's reconstructions (step 1) by

447 comparing the inferred allometric relationships between trunk diameters and tree 448 dimensions to allometric relationships derived from field measurements of tree height 449 and diameter. We computed the mean absolute and mean relative deviation (in \%) 450 between height predictions. For biomass, we compared our predictions to previous 451 estimates of plot biomass for both sites and landscape-scale maps obtained with a 452 pooled regression model, all reported in Labriere et. al. (2018). To more formally assess the extrapolation to landscape scale (step 2), we first

454 evaluated the consistency of the extrapolation model with the reference estimate, 455 derived from the field inventory and Canopy Constructor-calibrated allometries (step 1). 456 We did so by applying the extrapolation step to each plot itself and assessed the fit of the 457 extrapolation model. We quantified the accuracy and precision of biomass estimation 458 via four commonly reported metrics, namely $\mathrm{R}^{2}$ (squared Pearson's r), RMSE (root mean 459 squared error, $\mathrm{t} \mathrm{ha}^{-1}$ ), MAE (mean absolute error, $\mathrm{t} \mathrm{ha}^{-1}$ ) and MBE (mean bias of the 460 error, $\mathrm{t} \mathrm{ha}^{-1}$ ). All metrics, except $\mathrm{R}^{2}$, were also computed relative to the reference AGB. 461 We then evaluated the sensitivity to plot characteristics through a cross-validation 462 procedure where we used the summary statistics from one plot per study site 463 (calibration plot) to extrapolate to the other plot at the study site (extrapolation plot), 464 and vice versa. As before, we quantified accuracy with respect to reference AGB 465 estimates through $\mathrm{R}^{2}$, RMSE, MAE and MBE. Finally, we also compared the reference and 466 predicted diameter distributions, both for the model fit and in cross-validation. To evaluate the Canopy Constructor's utility for biomass estimates compared to 468 more conventional methods, we compared its accuracy to the accuracy of log-log 
regression models of AGB vs. median canopy height (Labriere et al., 2018; Réjou-

470 Méchain et al., 2015). We fitted log-log regression models against median canopy height,

471 again for each of the four plots at both 1 ha and 0.25 ha resolution and assessed both

472 model fit at the calibration plot and predictions between cross-validation plots. To

473 mirror the Canopy Constructor setup, we did not use any field-inferred height

474 allometries for the AGB estimates, but inferred height from a bioclimatic predictor

475 (Chave et al., 2014; Réjou-Méchain et al., 2017). Accuracy was reported with the same

476 metrics as above ( $\mathrm{R}^{2}$, RMSE, MAE, MBE).

477 Throughout this study, we carried out a comprehensive Bayesian inference with

47810,000 prior and 100 posterior simulations. This gave a good approximation of the

479 Canopy Constructor's posterior distributions, but, more importantly, also allowed us to

480 assess the method's sensitivity to simulation numbers. To this effect, we resampled 100

481 sets of 1,000 simulations from the 10,000 prior simulations, and 100 sets of 10

482 simulations from the 100 posterior simulations, and repeated both steps of the Canopy

483 Constructor to assess accuracy and precision in a computationally more efficient setting. 


\section{Results}

\subsection{Reconstructions of tropical forest canopies in 3D}

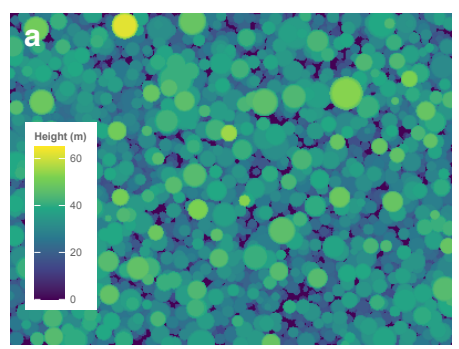
structure (panel c).
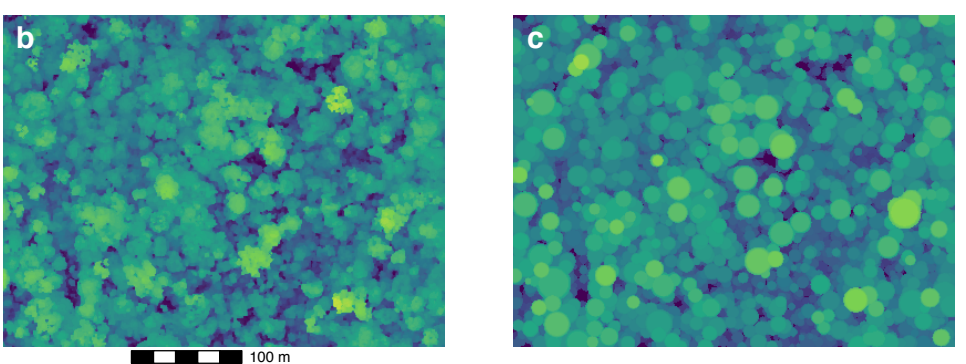

495

496

Across all plots, the Canopy Constructor yielded good fits for the canopies with a final error in mean canopy height of $0.66 \mathrm{~m}$ [95\% credibility interval: $-0.41,1.8]$ or $2.7 \%$ of mean canopy height, and a mean absolute error of $3.98 \mathrm{~m}[3.02,4.98]$ or $\sim 14.4 \%$ of mean canopy height. Figure 2 visualizes the approach at the Petit Plateau plot for a posterior simulation after 200 iterations of fitting. The initial draw (panel a) already mirrored average properties of the empirical canopy, but not the spatial location of its features (panel b). Swapping the deviations in allometries greatly improved the spatial

Figure 2: Example of canopy reconstruction at the Petit Plateau plot, Nouragues. Shown are the initial canopy height model (CHM) where tree dimensions are randomly drawn from site-specific allometries (a), the ALS-derived CHM (b), and the final reconstruction of the Canopy Constructor (c).

\subsection{Allometric scaling relationships}

Tree inventories and ALS data were sufficient to infer allometric relationships between tree dimensions at both sites. Across all plots, we found substantial covariation between allometric parameters (Table S1, and Figure S3, left panels), but height allometries had lower uncertainties than crown radius allometries (Figure 3, Figure S3, Table 1). High within-site similarity was found for height allometries at both Nouragues and Rabi (Figure 3). Crown allometries, on the other hand, showed a divergence at Nouragues, 

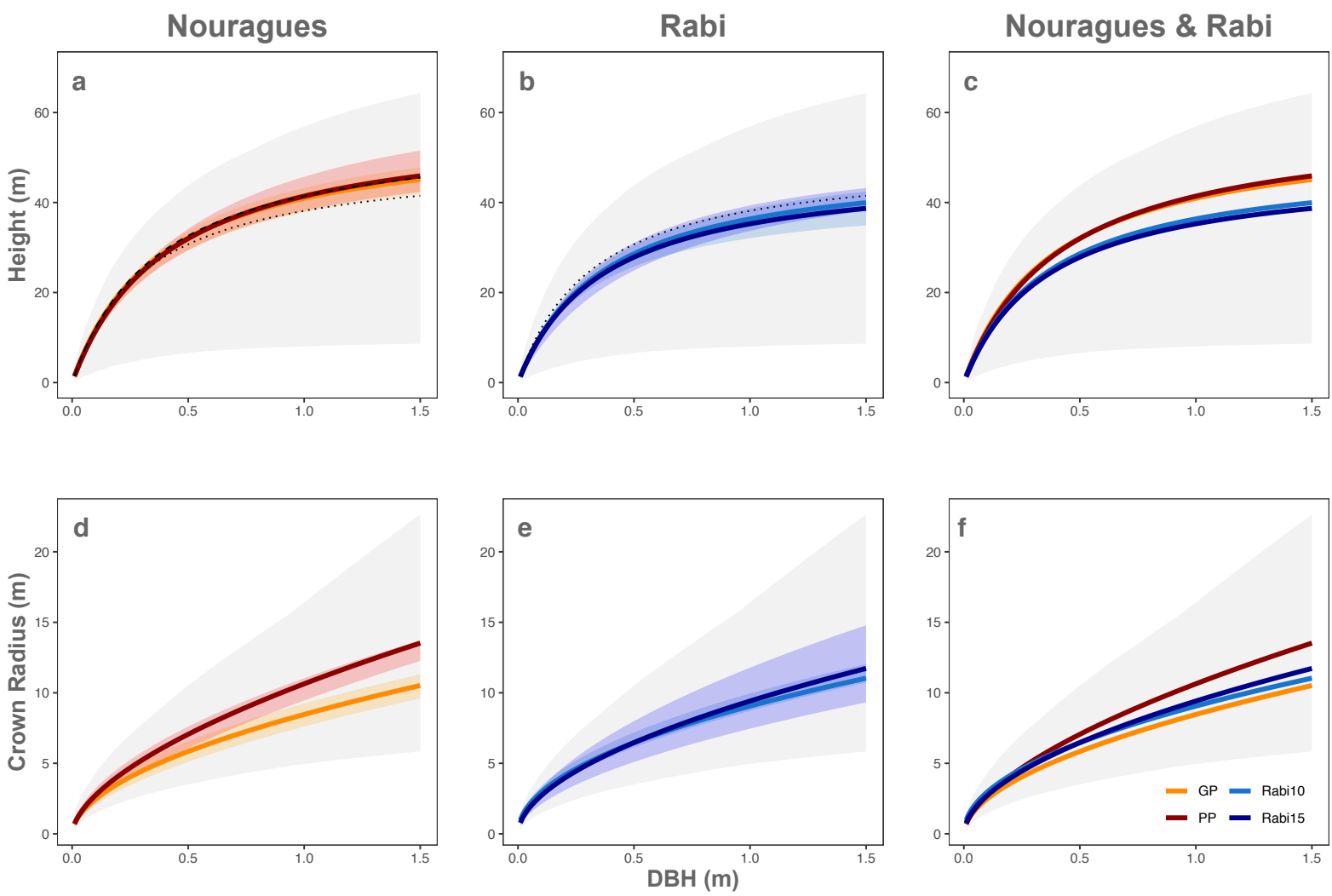

511 Figure 3: Inferred allometries at Nouragues and Rabi (step 1). The panels show height allometries

512 (top row) and crown allometries (bottom row), as inferred by the Canopy Constructor, for Nouragues

$513(a, d)$, Rabi $(b, e)$ and both sites combined $(c, f)$. The grey background indicates the prior range. Mean and

$51475 \%$ highest density intervals are given for each plot separately, i.e. for Grand Plateau (orange) and Petit

515 Plateau (dark red) at Nouragues, and for the 10ha (light blue) and 15ha (dark blue) plot at Rabi. As

516 comparison, we have plotted empirical height allometries measured from in the field for both Grand

517 Plateau (dotted) and Petit Plateau (dashed) in the top panels, as well as a single ground-inferred allometry

518 at Rabi (dotted). Results for same inference procedure, but with a lower number of simulation runs, are provided in Figure S8. 
522 field measurements of tree height (cf. Figure 3, top row). At Nouragues, the Canopy

523 Constructor's height estimates were slightly lower than empirical ones at small

524 diameters and exceeded them at large diameters, but mirrored their qualitative

525 patterns, i.e. the larger heights predicted at Petit Plateau compared to Grand Plateau.

526 The difference to empirical height predictions never exceeded $1 \mathrm{~m}$ (or $2 \%$ ) at Petit

527 Plateau, versus $3.2 \mathrm{~m}$ (or 7.8\%) at Grand Plateau. At Rabi, the pattern was inversed, with

528 lower predictions of tree height at large diameters than from empirical data, but

529 differences never exceeded 11\% (Supplementary Figure S4).

530 Table 1: Inferred parameters. Mean of posterior distributions for allometric parameters at the two sites.

531 Plots are Grand Plateau (GP) and Petit Plateau (PP) at Nouragues, and the 10 ha and 15 ha rectangular

532 strips at Rabi (Rabi10 and Rabi15, respectively). $\mathrm{a}_{\mathrm{h}}$ and $\mathrm{h}_{\max }$ are given in $\mathrm{m}$, all other variables are unitless.

533

534

535

536

537

538

539

540

541

542

$543 \sim 0.24)$ than at Nouragues $(\sim 0.16$, cf. also Figure 4, b and e). At both Nouragues and Rabi,

\subsection{Biomass mapping at landscape scale}

Aboveground biomass was estimated to be 400.8 t ha-1 $^{-1}$ at the Nouragues plots [366.2 437.9] and 302.2 t ha-1 $^{-1}[267.8,336.8]$ at Rabi. Within-site standard deviation at hectare scale was $105.1 \mathrm{t} \mathrm{ha}^{-1}[86.5,120.7]$ at Nouragues and $71.0 \mathrm{t} \mathrm{ha}^{-1}[60.5,83.6]$ at Rabi. At both sites, biomass density decreased at the landscape scale to an average of $299.8 \mathrm{t} \mathrm{ha}^{-1}$ [275.9, 333.9] and 251.8 t ha $^{-1}[206.7,291.7]$, respectively, but with considerable heterogeneity (Figure 4, a and d). Map uncertainty was highest at vegetation edges and low biomass areas, and generally higher at Rabi (median coefficient of variation of

\begin{tabular}{lllllll}
\hline & $\boldsymbol{a}_{\boldsymbol{h}}$ & $\boldsymbol{h}_{\boldsymbol{m a x}}$ & $\boldsymbol{\sigma}_{\boldsymbol{h}}$ & $\boldsymbol{a}_{\boldsymbol{C R}}$ & $\boldsymbol{b}_{\boldsymbol{C R}}$ & $\boldsymbol{\sigma}_{\boldsymbol{C R}}$ \\
\hline GP & 0.41 & 56.88 & 0.39 & 2.19 & 0.55 & 0.24 \\
PP & 0.39 & 58.38 & 0.23 & 2.29 & 0.56 & 0.22 \\
Rabi10 & 0.32 & 47.52 & 0.37 & 2.2 & 0.53 & 0.25 \\
Rabi15 & 0.28 & 43.67 & 0.35 & 2.23 & 0.55 & 0.27 \\
\hline
\end{tabular}
$\sim 0.24)$ than at Nouragues ( $\sim 0.16, \mathrm{cf}$ also Figure $4, \mathrm{~b}$ and $)$. At both Nouragues and Rabi, 

scale.

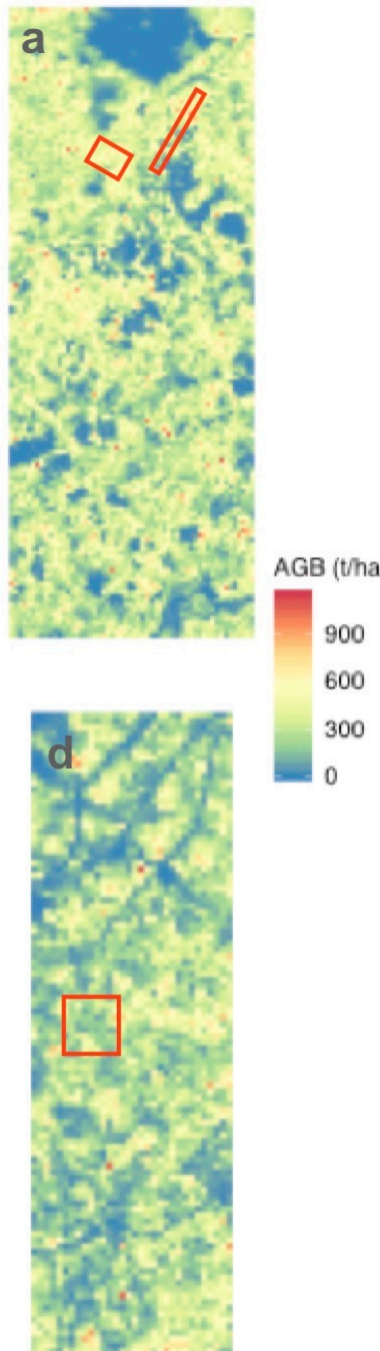
for visualization purposes.
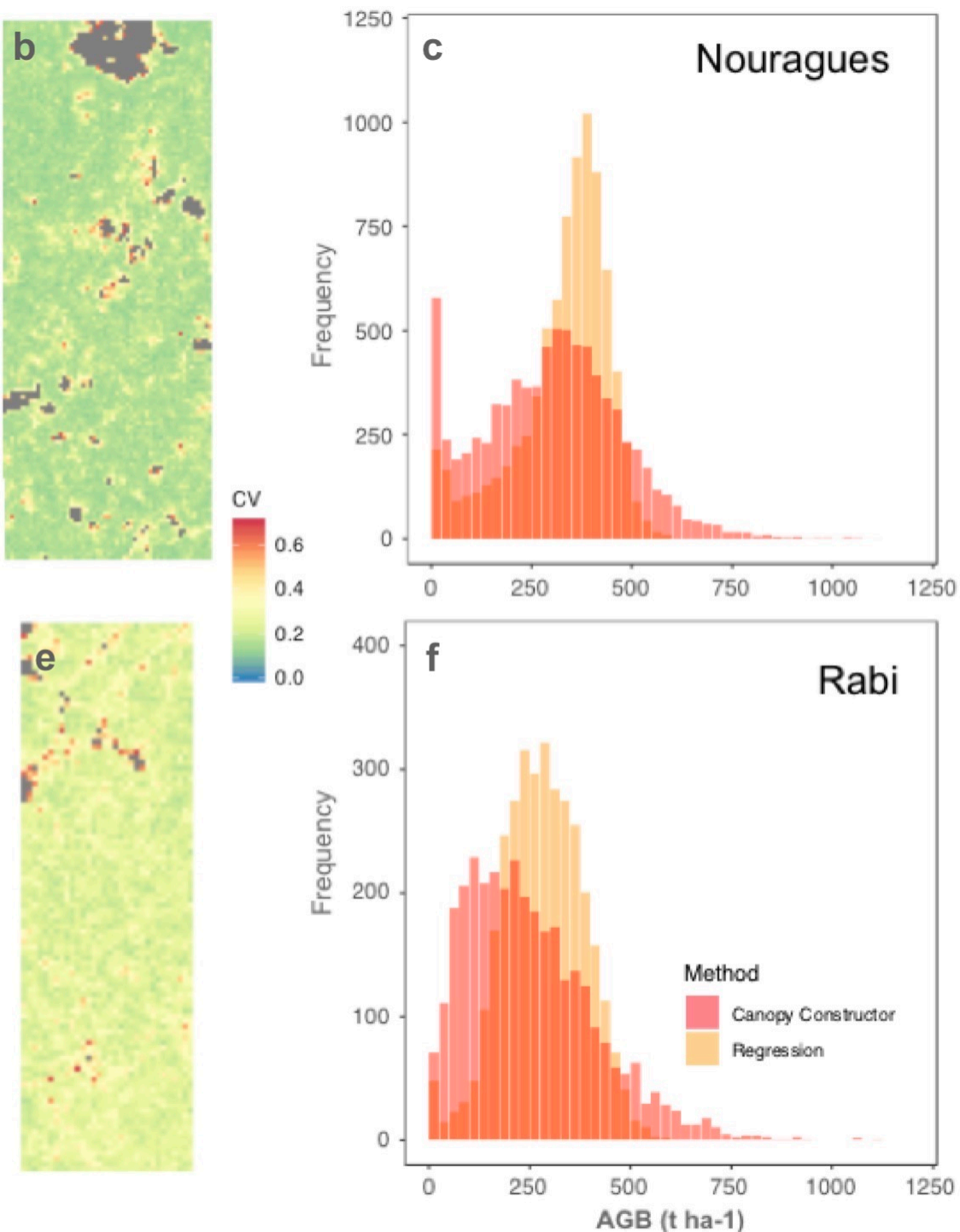

Figure 4: Aboveground biomass predictions for ALS campaign at Nouragues and Rabi (step 2).

Maps show the mean aboveground biomass values ( $\left.\mathrm{tha}^{-1}\right)$ predicted with the Canopy Constructor approach across 2,016 ha at Nouragues (panel a) and 832 ha at Rabi (panel d), as well as the respective coefficient of variation across 100 simulations (panels b and e, dimensionless). Also given are the overall distributions of aboveground biomass (panels $\mathrm{c}$ and f, red distributions, in t ha-1) and previously obtained estimates (panels c and f, yellow) from a pooled regression-model (Labrière et al. 2018). Clearly evident is the shrinkage towards the mean in the regression-based approach, as opposed to much stronger variation in the Canopy Constructor approach. Please note that the geographic extent of the maps has been rescaled 

404.6 tha-1 at the plot and $328.6 \mathrm{t} \mathrm{ha}^{-1}$ at landscape scale at Nouragues, and $314.6 \mathrm{t} \mathrm{ha}^{-1}$ 282 t ha-1 at Rabi (Labriere et al., 2018). However, the spread in aboveground biomass density was much larger than in previous biomass maps, with a larger fraction of both 560 low- and high-density grid cells (Figure 4, c and f).

\subsection{Extrapolation accuracy}

563 Across both sites, the extrapolation model's biomass predictions were consistent with

564 the locally inferred reference values (Figure 5, a and c), with an $\mathrm{R}^{2}$ of 0.84 at the 1 ha 565 scale, and 0.67 at the 0.25 ha scale. The RMSEs were 53.2 t ha $^{-1}(14.7 \%)$ and 87.3 t ha-1 $^{-1}$ 566 (24.1\%). The calibration plots were also representative of the local environment, as the 567 quality of the inference did not decrease in cross-validation, with identical $\mathrm{R}^{2}$ values and 568 similar RMSE as before, i.e. $53.7 \mathrm{t} \mathrm{ha}^{1}$ at the one-hectare scale, and 87.6 at the 0.25 ha 569 scale, or $14.9 \%$ and $24.2 \%$, respectively (Figure 5, b and d). The good predictive 570 accuracy was mirrored by diameter distributions that matched well empirical ones, both 571 when fit at the calibration site and in cross-validation (Figures S5 and S6, Table S2). Regression-based approaches generally produced better model fits at the

573 calibration sites than the Canopy Constructor, but there was no clear advantage in cross574 validation, with $\mathrm{R}^{2}=0.72$ at the 1 ha scale and 0.55 at the 0.25 ha scale, and an RMSE of $575 \quad 51.6 \mathrm{t} \mathrm{ha}^{-1}(14.6 \%)$ and $81.4 \mathrm{t} \mathrm{ha}^{-1}$ (18.3\%), respectively (Figure S7). Bias was slightly 576 higher in the Canopy Constructor, at $-4.7 \%$, compared to a $+1.2 \%$ in regression, but the 577 Canopy Constructor predicted much larger heterogeneity than the regression-based approach. In the calibration step, it had a 95\% range in AGB of $489.7 \mathrm{t} \mathrm{ha}^{-1}$, compared to $579458.5 \mathrm{t} \mathrm{ha}^{-1}$ at the 0.25 ha scale, and the difference was even larger in extrapolation, 580 with a predicted range of $568 \mathrm{t} \mathrm{ha}^{-1}$ against $368.3 \mathrm{t} \mathrm{ha}^{-1}$ from regression ( $54 \%$ increase). 


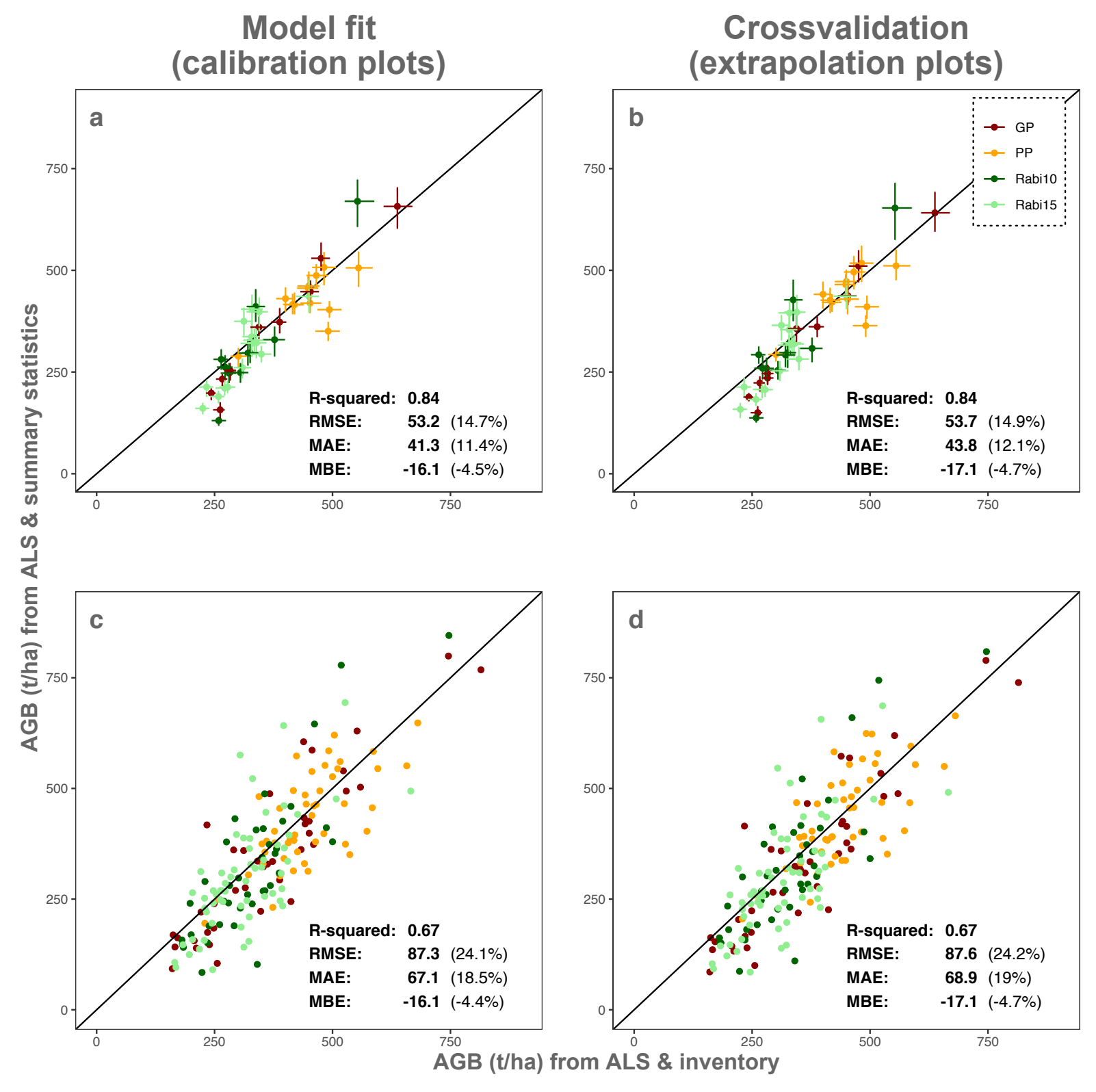

Figure 5: Evaluation of aboveground biomass predictions in extrapolation (step 2). Shown are the

predictions of aboveground biomass (median of 100 posterior simulations, given in $\mathrm{t} \mathrm{ha}^{-1}$ ) at the 1 ha scale

$584(a, b)$ and 0.25 ha scale (c, d). The left column shows the results when the space-filling approach is applied

585 at the calibration plot from which allometries and packing densities were derived ("Model fit"), the right

586 column the results when the approach is transferred between plots ("Cross- validation"). The Nouragues

587 results are plotted in red/orange, and for Rabi in dark/light green. Goodness of fit values are provided in

588 the bottom-right corner of the panels. MBE does not change between 0.25 and 1 ha scales and is thus only

589 given in the top panels. For visualization purposes, we only plot error bars at the hectare scale, representing the interquartile ranges of estimates from 100 posterior simulations. 
592 sets of simulations. Within plots, height allometric parameters were similar to the full

593 simulation set (example inference in Figure S8). Average AGB was also similar to the full

594 simulation set, with $399.2 \mathrm{t} \mathrm{ha}^{-1}$ at Nouragues and $305.0 \mathrm{t} \mathrm{ha}^{-1}$ at Rabi, and small

595 standard deviations of 5.7 t ha $^{-1}(1.4 \%)$ and 5.6 t ha $^{-1}(1.8 \%)$. The average $\mathrm{R}^{2}$ in

596 extrapolation was 0.65 at the 0.25 ha scale with an average RMSE of $90.7 \mathrm{t} \mathrm{ha}^{-1}$, and

597 standard deviations of 0.02 and $2.8 \mathrm{ha}^{-1}$, respectively (or $\sim 3 \%$ for both metrics).

598 


\section{Discussion}

600 We described and applied a new approach to quantifying forest structure, the Canopy

601 Constructor. The Canopy Constructor inputs local forest tree inventories and airborne

602 lidar scanning and outputs estimates of forest structure, allometric relationships among

603 tree dimensions and virtual landscape-scale tree inventories. These results provide

604 insights on tree allometric relationships and the distribution of carbon stocks. Below we

605 discuss how the method advances our knowledge on both issues, and we reflect on the

606 underlying assumptions and computational limitations. We applied our approach at two

607 tropical forest sites, one in the Guiana Shield of South America, the other in the Guineo-

608 Congolian rainforest of Africa. We selected the two sites because they are geographically 609 and floristically distinct, but represent high-carbon stock forests, those for which classic 610 airborne lidar scanning (ALS) methods of biomass mapping are the most error prone.

611 We also discuss whether the Canopy Constructor method is applicable beyond closed-

612 canopy tropical forests, e.g., in landscapes with land-use mosaics, and in temperate and 613 boreal forests.

614

\section{Inferring allometric relations in forest trees}

616 We used the first step of the Canopy Constructor in a Bayesian setting to infer the

617 allometric relationships between tree height and trunk diameter ( $\mathrm{dbh}$ ), and between

618 crown size and dbh. Such allometric relationships are essential for scaling up from

619 individual trees to forest canopies, and we found that they could be well-inferred from a 620 combination of field inventories and ALS data alone.

In particular, we found that height-diameter relationships differed more strongly

622 between than within sites, suggesting that biogeographic constraints at the macroscale

623 outweighed micro-environmental effects, such as disturbances, in shaping the two 
624 forests' height scaling relationships. Crown radius allometries, on the other hand, had

625 higher uncertainties and were not clearly separated between sites. However, the French

626 Guiana plots displayed considerable within-site differences in their crown radius

627 allometry. While trees generally show both plasticity in height growth and the lateral

628 extension of the crown (Henry and Aarssen, 1999, Jucker et al., 2015; Pretzsch and

629 Dieler, 2012), height growth is also strongly influenced by physiological limitations

630 (Niklas, 2007). Horizontal crown growth, on the other hand, may depend strongly on

631 canopy openings, particularly so for mid-sized canopy trees, which might explain why

632 we recorded such a notable difference at the Nouragues site, where the two plots have

633 very different disturbance regimes.

634 One key assumption of our approach is that a single functional form holds across

635 a wide range of environmental conditions, forest cover types and functional groups.

636 Specifically, equations (1) and (2) assume a Michaelis Menten model for the dbh-height

637 relationship, and a power-law model for the dbh-crown size relationship, and we make

638 the strong assumption that variation in tree architecture can be summarized by

639 variation in six pre-defined allometric parameters $\left(h_{\max }, a_{h}, \sigma_{h}, a_{c r}, b_{c r}, \sigma_{c r}\right)$. On the one

640 hand, there is considerable empirical evidence for global scaling relationhips between

641 plant dimensions (Jucker et al., 2017), and there are strong theoretical arguments for

642 their generality due to constraints on resource uptake and hydraulics (West et al., 1999;

643 Niklas, 1994; Niklas, 2007). On the other hand, physiological constraints depend on

644 climatic conditions and are shaped by the organisms' evolutionary history and

645 ecological niches (Niklas, 1994), so allometric relationships vary strongly across

646 environments, among species and co-vary with growth strategies and plant functional

647 traits (Cano et al., 2019; Lines et al., 2012). Empirical data also show deviations from

648 idealized allometric relationships due to disturbances and size-dependent competition 
among plants (Coomes et al., 2003). In light of this knowledge, there is currently not enough evidence that equations (1) and (2) are valid across all of the world's forest types. However, they are flexible enough to accommodate a wide range of tree forms and have been previously found to yield good fits at our study sites and for other

653 tropical rain forests (Labriere et al., 2018; Feldpausch, et. al. 2012). In tropical forests, in particular, the Michaelis-Menten functional form has been shown to well-represent the saturating scaling relationships between diameter and tree height (Molto et al., 2014, Cano et al., 2019) and is commonly used to improve biomass estimates (Feldpausch et al., 2012, Réjou-Méchain et al., 2017). However, field data on tree height are difficult to obtain, so the number of empirically derived dbh-height allometric models remains limited in the tropics (Sullivan et al., 2018). The retrieval of

660 crown radius is equally, if not more challenging in dense canopies. The Canopy 661 Constructor approach circumvents such data acquisition problems by parameterizing 662 the scaling relationships directly from a combination of geo-located trunk diameters and 663 ALS-derived canopy height models. At both our study sites, in French Guiana and Gabon, 664 the approach considerably narrowed down the parameter ranges for the inference of dbh-height tree allometries and dbh-crown radius allometries. Independent field data

666 for the dbh-height allometry further confirmed that our inference matched the 667 relationships derived from empirical measurements. The Canopy Constructor thus 668 provides an important approach to estimate tree crown dimensions and biomass 669 estimates where field measurements are scarce. The allometric models described in equations (1) and (2) account for inter-

671 individual variation in allometry through the parameters $\sigma_{h}, \sigma_{c r}$. For each allometry, a 672 single terms is thus used to model variation due to life histories (King, 1996), species 673 differences (Poorter et al., 2006; Thomas, 1996), and environmental conditions (Lines et 
al., 2012). If allometries were inferred for different species or different functional groups, much lower variation around allometric means would be expected, with a probable reduction in uncertainty and more accurate representation of the underlying

677 ecological relationships (Cano et al., 2019). However, there is also a tradeoff between increasing the number of model parameters to reduce uncertainty, and overfitting the model. Another risk is that few forest types currently have the level of information to implement species-specific versions of equations (1) and (2). In tropical forests, for example, there would likely not be enough field measurements to infer allometric relationships for rare species, and data might have to be pooled except for the most abundant species.

Recently, a wealth of information about tree allometry has been made available by the lidar scanning of entire trees from the ground (Dassot et al., 2011). Terrestrial lidar scanning (TLS) has reached a stage of maturity where it can now be applied to mixed-species forests, and even to all canopy trees from a stand (Calders et al., 2015; Momo Takoudjou et al., 2017; Newnham et al., 2015; Stovall et al., 2018). Furthermore, it allows the implementation of detailed canopy space-filling models (Pretzsch, 2014) and creates high-resolution renditions of the 3D architecture of individual trees. This novel source of information poses great challenges at the analysis stage (Åkerblom et al., 2017), but has become the best approach to test the generality of allometric exponents (Lau et al., 2019). In the future, it would be possible to either directly integrate TLS information into the Canopy Constructor at the parameter estimation stage (step 1), e.g. as an additional constraint on how the 3D voxel volume is filled, or to test the validity of the inferred scaling relationships.

This could be of particular value in heavily disturbed landscapes with few trees, where the simulation approach and its idealized crown shapes may fail to capture inter- 
individual variation in tree architecture. However, it would likely have the strongest benefits for small understory species that are mostly hidden from the Canopy

Constructor's fitting procedure. The latter do not only increase the range of allometries that fit the local forest plot and thus contribute strongly to the uncertainty in allometric inference, but they also increase the computational burden without considerably improving the 3D-fits . Nevertheless, it is vital to include small trees in our approach, since they reduce the bias in allometric estimates. Without them, the algorithm would extend crowns from the understory into gaps to improve the fit of the canopy height model and both underestimate tree heights and overestimate crown radii. An alternative to the Canopy Constructor approach is to search for individual crown features by tree crown segmentation of ALS point clouds (Aubry-Kientz et al., 2019; Dalponte and Coomes, 2016; Ferraz et al., 2016) and to mtach the crowns to stems on the ground. In the future, a merging of both techniques could prove interesting: the

Canopy Constructor algorithm has advantages for forest canopies where individual trees cannot be easily segmented, while individual tree crown segmentation methods are effective for emergent trees and more open forest landscapes. One option would be to first isolate easily identifiable trees, and then pass information on crown shape and size on to the Canopy Constructor. This would narrow down priors on allometric parameters and provide tie-points for the spatial fitting procedure.

Another important objective would be the improvement of the inference of crown radii, which showed higher uncertainty than inferred tree heights. So far, we did not impose any restrictions on crown overlap. This is at odds with observations (Goudie et al., 2009) and may have increased the uncertainty, since crowns can be hidden within each other. A solution could be the simulation of phototropism and plasticity (Purves et al., 2008; Strigul et al., 2008), or the incorporation of leaf-level constraints, e.g. a 
724 condition that assimilated carbon should be greater than respiration losses, as in the

725 TROLL model (Maréchaux and Chave, 2017). We hypothesize that this would restrict the

726 range of crown sizes, particularly in the understory where light limits tree growth.

\section{Virtual forest inventories and carbon mapping}

729

730

731

732

733

734

735

736

737

738

739

740

In the second step of the Canopy Constructor, the locally calibrated models are used to generate large-scale virtual tree inventories across thousands of hectares covered by ALS. We tested this approach at the two study sites and validated its performance through cross-validation. One of the main applications for these virtual tree inventories is the evaluation of carbon mitigation and conservation strategies.

Forest biomass is concentrated in a small number of large trees (Bastin et al., 2015; Lutz et al., 2018; Meyer et al., 2018), and mapping the spatial distribution of these trees is key to achieving high-resolution biomass estimates. Using ALS-data to extrapolate virtual inventories, the Canopy Constructor showed good predictive accuracy, mirroring well empirical tree densities and their biomass heterogeneity (Figure 4). The extrapolation uncertainty did not increase between the calibration and cross-validation plots. We validated this at Nouragues, where the plots have different disturbance regimes and different canopy height distributions (Figure S1). This suggests that the Canopy Constructor is an efficient method to map aboveground biomass across an entire landscape.

Specifically, the Canopy Constructor led to an improved biomass inference compared to regression-based approaches. Regression-based approaches, also known as area-based approaches (Coomes et al., 2017), infer mean stand biomass from ALSderived canopy features, such as mean or median canopy height (Asner and Mascaro, 2014; Næsset, 2002; Zolkos et al., 2013). However, all regression-based inferences tend 
to shrink the extreme values to the mean when uncertainty in the predicted variable is not propagated or when there is strong variation in the independent variable, a

751 phenomenon sometimes called "dilution" bias (Réjou-Méchain et al., 2014). Because the

752 Canopy Constructor factors in the influence of large trees and makes use of the whole 753 canopy height model, we expected that it would mitigate this issue. Indeed, we found a similar predictive accuracy for both methods, but the Canopy

755 Constructor better represented the heterogeneity of the canopy. The 95\% range of 756 biomass estimates at the 0.25 ha scale was higher across both Canopy Constructor steps, 757 with an overall increase of 54\% compared to an equivalent regression procedure.

758 Particularly noticeable were low biomass estimates for low-canopy forests that led to an 759 overall decrease in landscape-wide estimates at both Nouragues and Rabi compared to 760 previous biomass maps (Figure 4). Since many field inventories in the tropics are 761 established within primary forest, regression-based estimates are often calibrated on 762 tall canopies, and while additional field data would be required to validate this claim, it 763 may be that our individual-based approach better captures forest structure outside the 764 regression model's calibration range. Similarly, it likely better accounts for the large 765 multiplicative errors in tall canopies. Such fine-scale structural representations are 766 particularly important in identifying high-priority areas for carbon mitigation and 767 conservation, and when monitoring the impact of human interventions such as selective 768 logging on ecosystem functioning and animal habitats.

769 Furthermore, we hypothesize that there is considerable room for improvement of 770 future canopy reconstructions, since additional considerations on crown overlapping 771 and carbon balance or species' ecological strategies would likely improve the spatial 772 positioning of trees. The Canopy Constructor thus has the potential to be more widely 773 applicable across biomes and environmental conditions than currently used individual- 
or area-based models (Coomes et al., 2017) and could provide an efficient means to assimilate forest inventories and ALS surveys into high-resolution aboveground biomass maps for the validation of remote-sensing biomass missions (Duncanson et al., 2019; Le Toan et al., 2011).

Nevertheless, the accuracy of biomass predictions with the Canopy Constructor also depends on the quality and the representativeness of the calibration sites.

First, while we do not assume that stem diameter probability distributions are identical across the whole area, we assume that they are similar enough to sample the entire diameter range. Ideally, they should not considerably over- or underrepresent a particular size-class. When the calibration plot covers a sufficiently large area ( $\geq 10 \mathrm{ha}$ ), microenvironmental features are likely well-sampled, and the space-filling approach of the Canopy Constructor will mostly compensate for deviations. However, in more heterogeneous landscapes than the ones selected for this study, it is essential to ensure that calibration plots are representative of all vegetation types.

Second, we assume that the vertical distribution of crown packing density within the canopy, as described by the local packing density matrix, is representative of the whole lidar-covered area. This crown packing matrix provides within-canopy densities conditional on top-of-canopy height and thus reflects disturbance regimes visible in the canopy height distribution. At the study sites, we found that a 10-ha forest inventory was sufficient to provide robust estimates of biomass even if the plot was not representative of the sampled area, as shown in the Nouragues forest. So, even if more studies are needed to fully explore this issue, we conclude that the assumptions of the Canopy Constructor do not lead to serious bias in biomass mapping as long as the sampled area is large. 
799 the entire landscape. This raises the question of whether an allometric model is valid 800 beyond the stand where it was generated. Recently Jucker et al. (2017) have explored 801 the generality of allometric relationships, with the aim to inform the link between field 802 inventories and remote sensing. Compilation of empirical evidence suggests that some 803 allometric relationships among tree dimensions are applicable outside of the locality 804 where they have been constructed, but this may, again, need to be qualified if there is 805 strong regional environmental variation or shifts in species composition (Beirne et al., 806 2019, Lines et al., 2012). Provided that enough data were available, separate allometric 807 relationships for functional or species groups, likely more conserved across the 808 landscape, could alleviate this problem in the future.

809 One of the main issues in extrapolation are understory trees, as they do not show 810 up in the canopy height model and thus exclusively depend on the diameter

811 distributions and crown packing densities of the calibration plots. The assumption of 812 similar understory tree densities may be violated, for example due to browser pressure 813 (Anderson-Teixeira et al., 2015b) or when the forest is more or less fragmented than at 814 the calibration sites (Laurance et al., 2006). While the effect on biomass will be 815 comparatively weak, understory densities can have important consequences for 816 ecological dynamics, such as regrowth and resilience.

817 Here, we only had two calibration plots per site and they where either 818 immediately adjacent (Rabi) or geographically close to each other (Nouragues), so the 819 effect of spatial auto-correlation across the landscape could not be fully assessed. Any 820 changes in soil characteristics, topography and floristic composition that may generate 821 bias in our biomass maps, would, however, also affect regression-based approaches and 822 can only be solved by more accurate sampling (Babcock et al., 2015; Spriggs et al., 2019). 
823 Since most forest sites around the world involve small plots ( 0.25 ha or 1 ha) that are

824 spread out in space to sample heterogeneous environments, a future evaluation of the

825 Canopy Constructor's assumptions across forest types should not pose a problem.

826

827 Applicability across forest types and processing considerations

828 Many sites worldwide offer a combination of high-quality local forest inventories and

829 ALS surveys (Duncanson et al., 2019), but far fewer provide quantitative information on

830 the vertical arrangement of individual trees and within-canopy forest structure, so the

831 Canopy Constructor was designed to be as widely applicable as possible. It only requires

832 a canopy height model that covers the sampling area and a sufficiently large number of

833 stem diameter measurements to accurately sample the diameter distribution. These

834 conditions are likely already met within a few hectares in closed-canopy forests, and our

835 results at two tropical forest stands provide evidence for this hypothesis.

836

The Canopy Constructor should, however, also be applicable to temperate and

837 boreal forests, or more open landscapes, such as woodlands, savannas or heavily

838 disturbed forests. Variable crown shapes can be accomodated through a crown shape

839 parameter, ranging from cylindric to conic forms, and non-measured trees below a stem

840 diameter cutoff can be supplemented by drawing from power-law or exponential

841 functions, as done in the present study. Due to its simulation approach and need for

842 representative calibration data, the Canopy Constructor reaches its limits in

843 insufficiently or unequally sampled landscapes with low tree densities and strong

844 floristic variation, but there, tree crown delineation would likely perform well and could

845 complement it.

846 When applied across a wide range of forests, variation in wood density beyond

847 the species level and variation in biomass allometries beyond a global mean would need 
848 to be considered (Réjou-Méchain et al., 2017). This would likely further increase the

849 local heterogeneity of simulated canopies, differentiate out between different

850 successional stages and thus achieve a more realistic picture. However, since neither

851 wood density nor biomass directly affect the Canopy Constructor procedure and since

852 wood density is distributed normally around species means (Chave et al., 2009, Kattge et

853 al., 2011), both uncertainties could be propagated in a relatively simple way.

854 The main limitation of the Canopy Constructor compared to more conventional,

855 regression-based approaches are its computational requirements. On one core of an

856 Intel Skylake 6104 processor at $2.3 \mathrm{GHz}$, computational burden of the Canopy

857 Constructor was ca. 3 minutes for a simulation of the typical field inventory in this study

858 ( 10ha), with moderate memory needs ( 300 MB). For the full set of 10,000

859 simulations tested here, this amounted to $\sim 400 \mathrm{cpu}$ core hours per plot for allometric

860 inference and $\sim 700 \mathrm{cpu}$ core hours for reconstructing tree-by-tree assemblies at the

861 landscape scale. Reduced sets of simulations yielded nearly identical results, with very

862 low standard deviations of the estimates (typically 1-2\%, and always lower than 5\%)

863 but on our hardware, the approach still required 50-100 cpu core hours for a typical

864 data configuration. The procedure is thus beyond desktop computers at the moment, but

865 since simulations within step 1 or step 2 are fully independent, the inference procedure

866 can be parallelized and is relatively easily executed on a modern cluster.

867 For future reconstructions, there are a number of ways to reduce the Canopy

868 Constructor's runtime. The computationally most expensive part of the procedure is the

869 creation of precise spatial fits, because it involves the constant swapping of tree crown

870 variation across the whole plot. While this is crucial for spatial predictions of biomass

871 and forest structure, unbiased estimates of allometric scaling relationships may already

872 be possible with the initial, non-optimized canopy reconstruction. In this case, runtime 
873 reduces to a few seconds and becomes executable on a desktop computer or within an $\mathrm{R}$ 874 package. Furthermore, the two goodness-of-fit metrics currently employed may not 875 yield the best convergence time towards a spatially accurate canopy reconstruction, and 876 the use of a single, feature-based pattern recognition metric such as Earth Mover's 877 Distance (Rubner et al., 2000) may be preferable. Similarly, the rudimentary rejection878 based Approximate Bayesian Computation could also be replaced by sequential 879 approaches that converge more rapidly and can be analyzed with state-of-the-art tools 880 (Csilléry et al., 2012; Nunes and Prangle, 2015). However, what the Canopy Constructor lacks in computational rapidity, it makes up for in comprehensiveness. Where regression-based predictions address one question 883 at a time, the Canopy Constructor's individual-based approach infers a wide range of 884 canopy features simultaneously, most of which we have not explored in this study (e.g., 885 vertical stratification, tree overtopping, and exposure to wind, variation in tree densities and clustering). Furthermore, the simulation-based approach and its Bayesian

887 framework render the integration of further data sources, such as hyperspectral imaging 888 or photogrammetry, relatively straightforward. Such data could extend the approach 889 even further in space and time and increase its precision (Dalponte and Coomes, 2016;

890 Goodbody et al., 2019; Vaglio Laurin et al., 2014), or make use of species-specific 891 properties to predict variation in leaf functional traits and community composition. The 892 consideration of repeated ALS acquisitions could yield individual-based estimates of 893 mortality and growth. And, since it models every individual tree down to $1 \mathrm{~cm} \mathrm{dbh}$, the 894 Canopy Constructor could also be used to calibrate and initialize vegetation models, 895 particularly the individual-based forest TROLL model on which much of its code is based 896 (Maréchaux and Chave, 2017), thus contributing to a model-data synthesis at global 897 scales (Shugart et al., 2015). This could provide a link between existing 3D 
898

899

900

901

902

903

904

905

906

907

908

909

910

911

912

913

914

915

916

917

918

919

920

921

922

reconstruction approaches at local scales (Calders et al., 2018) and their extrapolation in space via ALS.

\section{Conclusion}

Tropical forests account for over half of the carbon stored in live tissue (Pan et al., 2011), and mapping these stocks at high resolution is essential to assess the impact of ongoing forest deforestation and degradation (Asner et al., 2010). One major challenge of carbon mapping in tropical regions is that national forest inventories are missing and that natural tropical forests are difficult to monitor using traditional forestry techniques (Schimel et al., 2015). Mapping carbon stocks accurately is of prime importance in global carbon cycle research because tropical deforestation is an important cause of anthropogenic carbon dioxide emissions, and a likely cause of major climatic shifts (Boisier et al., 2015; Nobre et al., 2016). The uncertainty of future anthropogenic pressures and climatic changes in African rain forests (Malhi et al., 2013) as well as the recent acceleration of deforestation in the Amazon can only increase the urgency of providing accurate and repeated methods for carbon stock monitoring (Amigo, 2020). The Canopy Constructor transforms information available at biomass validation sites (sensu Duncanson et al., 2019) into virtual tree inventories that best match empirically measured forest structure. This creates a unifying framework that brings together traditionally separate fields, such as the demographics of plant communities, their underlying physiological constraints and ecosystem functioning, and its results can be used as input for the upscaling to global scales (Dubayah et al., 2020), for dynamic vegetation modelling (F. J. Fischer et al., 2019) or for radiative transfer studies to test how remote sensing signals interact with vegetation, especially radar applications (Tebaldini et al., 2019). Such methods, creating virtual systems that mirror the 
923 complexity of real systems, considerably increase our ability to predict future vegetation

924 dynamics under increased human pressure and climatic changes.

925

926 Declaration of competing interest

927 The authors declare that they have no known competing financial interests or personal 928 relationships that could have appeared to influence the work reported in this paper.

\section{Acknowledgements}

932 We thank Isabelle Maréchaux for her helpful comments on an initial draft of the

933 manuscript. This work has benefitted from "Investissement d'Avenir" grants managed

934 by Agence Nationale de la Recherche (CEBA, ref. ANR-10-LABX-25-01; ANAEE-France:

935 ANR-11-INBS-0001, TULIP: ANR-10-LABX-0041), from CNES, and from ESA (CCI-

936 Biomass). This work was granted access to the HPC resources of CALMIP

937 supercomputing centre in Toulouse under allocation p17012. In Gabon, CENAREST

938 granted permission and provided personnel to establish and study the Rabi plot. Shell

939 Gabon, the society Compagnie des Bois du Gabon provided financial and logistical

940 support. ForestGEO provided technical advice and funding for fieldwork and data

941 analysis. This is contribution \#193 of the Gabon Biodiversity Program.

942 


\section{Literature}

944 Åkerblom, M., Raumonen, P., Mäkipää, R., Kaasalainen, M., 2017. Automatic tree species recognition with quantitative structure models. Remote Sens. Environ. 191, 1-12. https://doi.org/10.1016/j.rse.2016.12.002

Amigo, I., 2020. When will the Amazon hit a tipping point? Nature. https://doi.org/10.1038/d41586-020-00508-4

Anderson-Teixeira, K.J., Davies, S.J., Bennett, A.C., Gonzalez-Akre, E.B., Muller-Landau, H.C., Joseph Wright, S., Abu Salim, K., Almeyda Zambrano, A.M., Alonso, A., Baltzer, J.L., Basset, Y., Bourg, N.A., Broadbent, E.N., Brockelman, W.Y., Bunyavejchewin, S., Burslem, D.F.R.P., Butt, N., Cao, M., Cardenas, D., Chuyong, G.B., Clay, K., Cordell, S., Dattaraja, H.S., Deng, X., Detto, M., Du, X., Duque, A., Erikson, D.L., Ewango, C.E.N., Fischer, G.A., Fletcher, C., Foster, R.B., Giardina, C.P., Gilbert, G.S., Gunatilleke, N., Gunatilleke, S., Hao, Z., Hargrove, W.W., Hart, T.B., Hau, B.C.H., He, F., Hoffman, F.M., Howe, R.W., Hubbell, S.P., Inman-Narahari, F.M., Jansen, P.A., Jiang, M., Johnson, D.J., Kanzaki, M., Kassim, A.R., Kenfack, D., Kibet, S., Kinnaird, M.F., Korte, L., Kral, K., Kumar, J., Larson, A.J., Li, Y., Li, X., Liu, S., Lum, S.K.Y., Lutz, J.A., Ma, K., Maddalena, D.M., Makana, J.R., Malhi, Y., Marthews, T., Mat Serudin, R., Mcmahon, S.M., McShea, W.J., Memiaghe, H.R., Mi, X., Mizuno, T., Morecroft, M., Myers, J.A., Novotny, V., de Oliveira, A.A., Ong, P.S., Orwig, D.A., Ostertag, R., den Ouden, J., Parker, G.G., Phillips, R.P., Sack, L., Sainge, M.N., Sang, W., Sri-ngernyuang, K., Sukumar, R., Sun, I.F., Sungpalee, W., Suresh, H.S., Tan, S., Thomas, S.C., Thomas, D.W., Thompson, J., Turner, B.L., Uriarte, M., Valencia, R., Vallejo, M.I., Vicentini, A., Vrška, T., Wang, Xihua, Wang, Xugao, Weiblen, G., Wolf, A., Xu, H., Yap, S., Zimmerman, J., $2015 a$. CTFS-ForestGEO: A worldwide network monitoring forests in an era of global change. Glob. Chang. Biol. 21, 528-549. https://doi.org/10.1111/gcb.12712 
Anderson-Teixeira, K.J., Mcgarvey, J.C., Muller-Landau, H.C., Park, J.Y., Gonzalez-Akre, E.B., Herrmann, V., Bennett, A.C., So, C. V., Bourg, N.A., Thompson, J.R., Mcmahon, S.M., Mcshea, W.J., 2015b. Size-related scaling of tree form and function in a mixedage forest. Funct. Ecol. 29, 1587-1602. https://doi.org/10.1111/1365-2435.12470

Antin, C., Pélissier, R., Vincent, G., Couteron, P., 2013. Crown allometries are less responsive than stem allometry to tree size and habitat variations in an Indian monsoon forest. Trees - Struct. Funct. 27, 1485-1495. https://doi.org/10.1007/s00468-013-0896-7

Asner, G.P., Mascaro, J., 2014. Mapping tropical forest carbon: Calibrating plot estimates to a simple LiDAR metric. Remote Sens. Environ. 140, 614-624. https://doi.org/10.1016/j.rse.2013.09.023

Asner, G.P., Powell, G.V.N., Mascaro, J., Knapp, D.E., Clark, J.K., Jacobson, J., KennedyBowdoin, T., Balaji, A., Paez-Acosta, G., Victoria, E., Secada, L., Valqui, M., Hughes, R.F., 2010. High-resolution forest carbon stocks and emissions in the Amazon. Proc. Natl. Acad. Sci. U. S. A. 107, 16738-16742. https://doi.org/10.1073/pnas.1004875107

Atkins, J.W., Bohrer, G., Fahey, R.T., Hardiman, B.S., Morin, T.H., Stovall, A.E.L., Zimmerman, N., Gough, C.M., 2018. Quantifying vegetation and canopy structural complexity from terrestrial LiDAR data using the forestr r package. Methods Ecol. Evol. 9, 2057-2066. https://doi.org/10.1111/2041-210X.13061

Aubry-Kientz, M., Dutrieux, R., Ferraz, A., Saatchi, S., Hamraz, H., Williams, J., Coomes, D., Piboule, A., Vincent, G., 2019. A comparative assessment of the performance of individual tree crowns delineation algorithms from ALS data in tropical forests. Remote Sens. 11. https://doi.org/10.3390/rs11091086

Babcock, C., Finley, A.O., Bradford, J.B., Kolka, R., Birdsey, R., Ryan, M.G., 2015. LiDAR 
based prediction of forest biomass using hierarchical models with spatially varying coefficients. Remote Sens. Environ. 169, 113-127. https://doi.org/10.1016/j.rse.2015.07.028

Bastin, J.F., Barbier, N., Réjou-Méchain, M., Fayolle, A., Gourlet-Fleury, S., Maniatis, D., De Haulleville, T., Baya, F., Beeckman, H., Beina, D., Couteron, P., Chuyong, G., Dauby, G., Doucet, J.L., Droissart, V., Dufrêne, M., Ewango, C., Gillet, J.F., Gonmadje, C.H., Hart, T., Kavali, T., Kenfack, D., Libalah, M., Malhi, Y., Makana, J.R., Pélissier, R., Ploton, P., Serckx, A., Sonké, B., Stevart, T., Thomas, D.W., De Cannière, C., Bogaert, J., 2015. Seeing Central African forests through their largest trees. Sci. Rep. 5. https://doi.org/10.1038/srep13156

Beirne, C., Miao, Z., Nuñez, C.L., Medjibe, V.P., Saatchi, S., White, L.J.T., Poulsen, J.R., 2019. Landscape-level validation of allometric relationships for carbon stock estimation reveals bias driven by soil type. Ecol. Appl. https://doi.org/10.1002/eap.1987

Blanchard, E., Birnbaum, P., Ibanez, T., Boutreux, T., Antin, C., Ploton, P., Vincent, G., Pouteau, R., Vandrot, H., Hequet, V., Barbier, N., Droissart, V., Sonké, B., Texier, N., Kamdem, N.G., Zebaze, D., Libalah, M., Couteron, P., 2016. Contrasted allometries between stem diameter, crown area, and tree height in five tropical biogeographic

1012 Boisier, J.P., Ciais, P., Ducharne, A., Guimberteau, M., 2015. Projected strengthening of 1013 areas. Trees - Struct. Funct. 30, 1953-1968. https://doi.org/10.1007/s00468-016-

Bohn, F.J., Huth, A., 2017. The importance of forest structure to biodiversity-productivity relationships. R. Soc. Open Sci. 4, 160521. https://doi.org/10.1098/rsos.160521

1017 Calders, K., Newnham, G., Burt, A., Murphy, S., Raumonen, P., Herold, M., Culvenor, D., 
Avitabile, V., Disney, M., Armston, J., Kaasalainen, M., 2015. Nondestructive estimates of above-ground biomass using terrestrial laser scanning. Methods Ecol. Evol. 6, 198-208. https://doi.org/10.1111/2041-210X.12301

Calders, K., Origo, N., Burt, A., Disney, M., Nightingale, J., Raumonen, P., Åkerblom, M., Malhi, Y., Lewis, P., 2018. Realistic forest stand reconstruction from terrestrial LiDAR for radiative transfer modelling. Remote Sens. 10, 933. https://doi.org/10.3390/rs10060933

Cano, I.M., Muller-Landau, H.C., Joseph Wright, S., Bohlman, S.A., Pacala, S.W., 2019. Tropical tree height and crown allometries for the Barro Colorado Nature Monument, Panama: A comparison of alternative hierarchical models incorporating interspecific variation in relation to life history traits. Biogeosciences 16, 847-862. https://doi.org/10.5194/bg-16-847-2019

Chalom, A., Mandai, C., Prado, P., 2013. Sensitivity analyses: a brief tutorial with Rpackage pse. Cran.Rstudio.Com 1-14.

Chave, J., Coomes, D., Jansen, S., Lewis, S.L., Swenson, N.G., Zanne, A.E., 2009. Towards a worldwide wood economics spectrum. Ecol. Lett. 12, 351-366. https://doi.org/10.1111/j.1461-0248.2009.01285.x

Chave, J., Olivier, J., Bongers, F., Châtelet, P., Forget, P.-M., van der Meer, P., Norden, N., Riéra, B., Charles-Dominique, P., 2008a. Above-ground biomass and productivity in a rain forest of eastern South America. J. Trop. Ecol. 24, 355-366. https://doi.org/10.1017/s0266467408005075

Chave, J., Réjou-Méchain, M., Búrquez, A., Chidumayo, E., Colgan, M.S., Delitti, W.B.C., Duque, A., Eid, T., Fearnside, P.M., Goodman, R.C., Henry, M., Martínez-Yrízar, A., Mugasha, W.A., Muller-Landau, H.C., Mencuccini, M., Nelson, B.W., Ngomanda, A., Nogueira, E.M., Ortiz-Malavassi, E., Pélissier, R., Ploton, P., Ryan, C.M., Saldarriaga, 

J.G., Vieilledent, G., 2014. Improved allometric models to estimate the aboveground biomass of tropical trees. Glob. Chang. Biol. 20, 3177-3190. https://doi.org/10.1111/gcb.12629

Chazdon, R.L., Broadbent, E.N., Rozendaal, D.M.A., Bongers, F., Zambrano, A.M.A., Aide, T.M., Balvanera, P., Becknell, J.M., Boukili, V., Brancalion, P.H.S., Craven, D., AlmeidaCortez, J.S., Cabral, G.A.L., De Jong, B., Denslow, J.S., Dent, D.H., DeWalt, S.J., Dupuy, J.M., Durán, S.M., Espírito-Santo, M.M., Fandino, M.C., César, R.G., Hall, J.S., Hernández-Stefanoni, J.L., Jakovac, C.C., Junqueira, A.B., Kennard, D., Letcher, S.G., Lohbeck, M., Martínez-Ramos, M., Massoca, P., Meave, J.A., Mesquita, R., Mora, F., Muñoz, R., Muscarella, R., Nunes, Y.R.F., Ochoa-Gaona, S., Orihuela-Belmonte, E., Peña-Claros, M., Pérez-García, E.A., Piotto, D., Powers, J.S., Rodríguez-Velazquez, J., Romero-Pérez, I.E., Ruíz, J., Saldarriaga, J.G., Sanchez-Azofeifa, A., Schwartz, N.B., Steininger, M.K., Swenson, N.G., Uriarte, M., Van Breugel, M., Van Der Wal, H., Veloso, M.D.M., Vester, H., Vieira, I.C.G., Bentos, T.V., Williamson, G.B., Poorter, L., 2016. Carbon sequestration potential of second-growth forest regeneration in the Latin American tropics. Sci. Adv. 2, e1501639. https://doi.org/10.1126/sciadv.1501639

Condit, R., 1998. Tropical Forest Census Plots, Tropical Forest Census Plots. https://doi.org/10.1007/978-3-662-03664-8

Coomes, D.A., Asner, G.P., Lewis, S.L., Dalponte, M., Phillips, O.L., Qie, L., Nilus, R., Phua, M.-H., Banin, L.F., Burslem, D.F.R.P., Jucker, T., 2017. Area-based vs tree-centric approaches to mapping forest carbon in Southeast Asian forests from airborne laser scanning data. Remote Sens. Environ. 194, 77-88. https://doi.org/10.1016/j.rse.2017.03.017

Coomes, D.A., Duncan, R.P., Allen, R.B., Truscott, J., 2003. Disturbances prevent stem sizedensity distributions in natural forests from following scaling relationships. Ecol. 
Lett. 6, 980-989. https://doi.org/10.1046/j.1461-0248.2003.00520.x

1069

1070

1071

1072

1073

1074

1075

1076

1077

1078

1079

1080

1081

1082

1083

1084

1085

1086

1087

1088

1089

1090

1091

1092

Csilléry, K., Blum, M.G.B., Gaggiotti, O.E., François, O., 2010. Approximate Bayesian Computation $(\mathrm{ABC})$ in practice. Trends Ecol. Evol. https://doi.org/10.1016/j.tree.2010.04.001

Csilléry, K., François, O., Blum, M.G.B., 2012. Abc: An R package for approximate Bayesian computation (ABC). Methods Ecol. Evol. 3, 475-479. https://doi.org/10.1111/j.2041-210X.2011.00179.x

Dalponte, M., Coomes, D.A., 2016. Tree-centric mapping of forest carbon density from airborne laser scanning and hyperspectral data. Methods Ecol. Evol. 7, 1236-1245. https://doi.org/10.1111/2041-210X.12575

Davis, K.T., Dobrowski, S.Z., Holden, Z.A., Higuera, P.E., Abatzoglou, J.T., 2019. Microclimatic buffering in forests of the future: the role of local water balance. Ecography (Cop.). 42, 1-11. https://doi.org/10.1111/ecog.03836

DeRose, R.J., Long, J.N., 2014. Resistance and Resilience: A Conceptual Framework for Silviculture. For. Sci. 60, 1205-1212. https://doi.org/10.5849/forsci.13-507

Disney, M., 2019. Terrestrial LiDAR: a three-dimensional revolution in how we look at trees. New Phytol. 222, 1736-1741. https://doi.org/10.1111/nph.15517

Dassot, M., Constant, T., Fournier, M., 2011. The use of terrestrial LiDAR technology in forest science: Application fields, benefits and challenges. Ann. For. Sci. 68, 959974. https://doi.org/10.1007/s13595-011-0102-2

Dowle, M., Srinivasan, A., 2018. data.table: Extension of “data.frame”. R package version 1.11.2. https://cran.r-project.org/package=data.table.

Dubayah, R., Blair, J.B., Goetz, S., Fatoyinbo, L., Hansen, M., Healey, S., Hofton, M., Hurtt, G., Kellner, J., Luthcke, S., Armston, J., Tang, H., Duncanson, L., Hancock, S., Jantz, P., Marselis, S., Patterson, P., Qi, W., Silva, C., 2020. The Global Ecosystem Dynamics 

Investigation: High-resolution laser ranging of the Earth's forests and topography. Sci. Remote Sens. 100002. https://doi.org/10.1016/j.srs.2020.100002

Duncanson, L., Armston, J., Disney, M., Avitabile, V., Barbier, N., Calders, K., Carter, S., Chave, J., Herold, M., Crowther, T.W., Falkowski, M., Kellner, J.R., Labrière, N., Lucas, R., MacBean, N., McRoberts, R.E., Meyer, V., Næsset, E., Nickeson, J.E., Paul, K.I., Phillips, O.L., Réjou-Méchain, M., Román, M., Roxburgh, S., Saatchi, S., Schepaschenko, D., Scipal, K., Siqueira, P.R., Whitehurst, A., Williams, M., 2019. The Importance of Consistent Global Forest Aboveground Biomass Product Validation. Surv. Geophys. 40, 979-999. https://doi.org/10.1007/s10712-019-09538-8

Engone Obiang, N.L., Kenfack, D., Picard, N., Lutz, J.A., Bissiengou, P., Memiaghe, H.R., Alonso, A., 2019. Determinants of spatial patterns of canopy tree species in a tropical evergreen forest in Gabon. J. Veg. Sci. 30, 929-939. https://doi.org/10.1111/jvs.12778

Farrior, C.E., Bohlman, S.A., Hubbell, S., Pacala, S.W., 2016. Dominance of the suppressed: Power-law size structure in tropical forests. Science 351, 155-157. https://doi.org/10.1126/science.aad0592

Fassnacht, F.E., Latifi, H., Hartig, F., 2018. Using synthetic data to evaluate the benefits of large field plots for forest biomass estimation with LiDAR. Remote Sens. Environ. 213, 115-128. https://doi.org/10.1016/j.rse.2018.05.007

Fatoyinbo, L., Pinto, N., Hofton, M., Simard, M., Blair, B., Saatchi, S., Lou, Y., Dubayah, R., Hensley, S., Armston, J., Duncanson, L., Lavalle, M., 2017. The 2016 NASA AfriSAR campaign: Airborne SAR and Lidar measurements of tropical forest structure and biomass in support of future satellite missions, in: International Geoscience and Remote Sensing Symposium (IGARSS). pp. 4286-4287. https://doi.org/10.1109/IGARSS.2017.8127949 
1118 Feldpausch, T.R., Lloyd, J., Lewis, S.L., Brienen, R.J.W., Gloor, M., Monteagudo Mendoza, A., 1119 Lopez-Gonzalez, G., Banin, L., Abu Salim, K., Affum-Baffoe, K., Alexiades, M., Almeida, 1120 S., Amaral, I., Andrade, A., Aragão, L.E.O.C., Araujo Murakami, A., Arets, E.J.M., 1121 Arroyo, L., Aymard C., G.A., Baker, T.R., Bánki, O.S., Berry, N.J., Cardozo, N., Chave, J., Comiskey, J.A., Alvarez, E., De Oliveira, A., Di Fiore, A., Djagbletey, G., Domingues, T.F., Erwin, T.L., Fearnside, P.M., França, M.B., Freitas, M.A., Higuchi, N., Honorio C., E., Iida, Y., Jiménez, E., Kassim, A.R., Killeen, T.J., Laurance, W.F., Lovett, J.C., Malhi, Y., Marimon, B.S., Marimon-Junior, B.H., Lenza, E., Marshall, A.R., Mendoza, C., Metcalfe, D.J., Mitchard, E.T.A., Neill, D.A., Nelson, B.W., Nilus, R., Nogueira, E.M., Parada, A., S.H. Peh, K., Pena Cruz, A., Peñuela, M.C., Pitman, N.C.A., Prieto, A., Quesada, C.A., Ramírez, F., Ramírez-Angulo, H., Reitsma, J.M., Rudas, A., Saiz, G., Salomão, R.P., Schwarz, M., Silva, N., Silva-Espejo, J.E., Silveira, M., Sonké, B., Stropp, J., Taedoumg,

Ferraz, A., Saatchi, S., Mallet, C., Meyer, V., 2016. Lidar detection of individual tree size in tropical forests. Remote Sens. Environ. 183, 318-333.

Fischer, F.J., Maréchaux, I., Chave, J., 2019. Improving plant allometry by fusing forest

Fischer, R., Knapp, N., Bohn, F., Shugart, H.H., Huth, A., 2019. The Relevance of Forest Structure for Biomass and Productivity in Temperate Forests: New Perspectives for Remote Sensing. Surv. Geophys. 1-26. https://doi.org/10.1007/s10712-019- 
1144 Garnier, S., 2018. viridis: Default Color Maps from “matplotlib.” R Packag. version 0.5.1.

1145 Goetz, S.J., Steinberg, D., Betts, M.G., Holmes, R.T., Doran, P.J., Dubayah, R., Hofton, M., 1146 2010. Lidar remote sensing variables predict breeding habitat of a Neotropical 1147 migrant bird. Ecology 91, 1569-1576. https://doi.org/10.1890/09-1670.1

1148 Goodbody, T.R.H., Coops, N.C., White, J.C., 2019. Digital Aerial Photogrammetry for 1149 Updating Area-Based Forest Inventories: A Review of Opportunities, Challenges, 1150 and Future Directions. Curr. For. Reports. https://doi.org/10.1007/s40725-01900087-2

1152 Grassi, G., House, J., Dentener, F., Federici, S., Den Elzen, M., Penman, J., 2017. The key 1153 role of forests in meeting climate targets requires science for credible mitigation. 1154 Nat. Clim. Chang. 7, 220-226. https://doi.org/10.1038/nclimate3227

1155 Hartig, F., Calabrese, J.M., Reineking, B., Wiegand, T., Huth, A., 2011. Statistical inference 1156 for stochastic simulation models - theory and application. Ecol. Lett. 14, 816-827. https://doi.org/10.1111/j.1461-0248.2011.01640.x

1158 Hartig, F., Dislich, C., Wiegand, T., Huth, A., 2014. Technical note: Approximate bayesian parameterization of a process-based tropical forest model. Biogeosciences 11,

1161 Henry, H.A.L., Aarssen, L.W., 1999. The interpretation of stem diameter-height allometry 1162 in trees: Biomechanical constraints, neighbour effects, or biased regressions? Ecol. 1163 Lett. 2, 89-97. https://doi.org/10.1046/j.1461-0248.1999.22054.x 1164 Hijmans, R.J., 2016. raster: Geographic Data Analysis and Modeling. R package version 1165 2.5-8. R Packag.

1166 Hill, R.W., Holland, P.W., 1977. Two Robust Alternatives to Least-Squares Regression. J. 1167 Am. Stat. Assoc. 72, 828-833. https://doi.org/10.2307/2286469 
1168 Hurtt, G.C., Dubayah, R., Drake, J., Moorcroft, P.R., Pacala, S.W., Blair, J.B., Fearon, M.G., 1169 2004. Beyond potential vegetation: Combining lidar data and a height-structured 1170 model for carbon studies. Ecol. Appl. 14, 873-883. https://doi.org/10.1890/02$1171 \quad 5317$

1172 Hyyppä, J., Inkinen, M., 1999. Detecting and estimating attributes for single trees using laser scanner. Photogramm. J. Finl. 16, 27-42.

1174 Inman, H.F., Bradley, E.L., 1989. The Overlapping Coefficient as a Measure of Agreement 1175 Between Probability Distributions and Point Estimation of the Overlap of two 1176 Normal Densities. Commun. Stat. - Theory Methods 18, 3851-3874. https://doi.org/10.1080/03610928908830127

1178 Isenburg, M., 2018. LAStools - efficient LiDAR processing software.

1179 Jucker, T., Bouriaud, O., Coomes, D.A., 2015. Crown plasticity enables trees to optimize $1180 \quad$ canopy packing in mixed-species forests. Funct. Ecol. 29, 1078-1086. https://doi.org/10.1111/1365-2435.12428

1182 Jucker, T., Caspersen, J., Chave, J., Antin, C., Barbier, N., Bongers, F., Dalponte, M., van 1183 Ewijk, K.Y., Forrester, D.I., Haeni, M., Higgins, S.I., Holdaway, R.J., Iida, Y., Lorimer, C., 1184 Marshall, P.L., Momo, S., Moncrieff, G.R., Ploton, P., Poorter, L., Rahman, K.A., 1185 Schlund, M., Sonké, B., Sterck, F.J., Trugman, A.T., Usoltsev, V.A., Vanderwel, M.C., 1186 Waldner, P., Wedeux, B.M.M., Wirth, C., Wöll, H., Woods, M., Xiang, W., Zimmermann, 1187 N.E., Coomes, D.A., 2017. Allometric equations for integrating remote sensing 1188 imagery into forest monitoring programmes. Glob. Chang. Biol. 23, 177-190. 1189 https://doi.org/10.1111/gcb.13388

1190 Kattge, J., Díaz, S., Lavorel, S., Prentice, I.C., Leadley, P., Bönisch, G., Garnier, E., Westoby, 1191 M., Reich, P.B., Wright, I.J., Cornelissen, J.H.C., Violle, C., Harrison, S.P., Van Bodegom, 1192 P.M., Reichstein, M., Enquist, B.J., Soudzilovskaia, N.A., Ackerly, D.D., Anand, M., 
Atkin, O., Bahn, M., Baker, T.R., Baldocchi, D., Bekker, R., Blanco, C.C., Blonder, B., Bond, W.J., Bradstock, R., Bunker, D.E., Casanoves, F., Cavender-Bares, J., Chambers, J.Q., Chapin, F.S., Chave, J., Coomes, D., Cornwell, W.K., Craine, J.M., Dobrin, B.H., Duarte, L., Durka, W., Elser, J., Esser, G., Estiarte, M., Fagan, W.F., Fang, J., FernándezMéndez, F., Fidelis, A., Finegan, B., Flores, O., Ford, H., Frank, D., Freschet, G.T.,

King, D.A., 1996. Allometry and life history of tropical trees. J. Trop. Ecol. 12, 25-44.

Khosravipour, A., Skidmore, A.K., Isenburg, M., Wang, T., Hussin, Y.A., 2014. Generating Pit-free Canopy Height Models from Airborne Lidar. Photogramm. Eng. Remote Sens. 80, 863-872. https://doi.org/10.14358/PERS.80.9.863

1217 Knapp, N., Fischer, R., Huth, A., 2018. Linking lidar and forest modeling to assess 
biomass estimation across scales and disturbance states. Remote Sens. Environ. 205, 199-209. https://doi.org/10.1016/j.rse.2017.11.018

Labriere, N., Tao, S., Chave, J., Scipal, K., Toan, T. Le, Abernethy, K., Alonso, A., Barbier, N., Bissiengou, P., Casal, T., Davies, S.J., Ferraz, A., Herault, B., Jaouen, G., Jeffery, K.J., Kenfack, D., Korte, L., Lewis, S.L., Malhi, Y., Memiaghe, H.R., Poulsen, J.R., RejouMechain, M., Villard, L., Vincent, G., White, L.J.T., Saatchi, S., 2018. In Situ Reference Datasets from the TropiSAR and AfriSAR Campaigns in Support of Upcoming Spaceborne Biomass Missions. IEEE J. Sel. Top. Appl. Earth Obs. Remote Sens. 11, 3617-3627. https://doi.org/10.1109/JSTARS.2018.2851606

Lau, A., Martius, C., Bartholomeus, H., Shenkin, A., Jackson, T., Malhi, Y., Herold, M.,

Laurance, W.F., Nascimento, H.E.M., Laurance, S.G., Andrade, A., Ribeiro, J.E.L.S., Giraldo, J.P., Lovejoy, T.E., Condit, R., Chave, J., Harms, K.E., D’Angelo, S., 2006. Rapid decay of tree-community composition in Amazonian forest fragments. Proc. Natl. Acad. Sci.

Levick, S.R., Asner, G.P., 2013. The rate and spatial pattern of treefall in a savanna landscape. Biol. Conserv. 157, 121-127. https://doi.org/10.1016/j.biocon.2012.07.009 
Lewis, S.L., Edwards, D.P., Galbraith, D., 2015. Increasing human dominance of tropical forests. Science 349, 827 - 832. https://doi.org/10.1126/science.aaa9932

Lines, E.R., Zavala, M.A., Purves, D.W., Coomes, D.A., 2012. Predictable changes in aboveground allometry of trees along gradients of temperature, aridity and competition. Glob. Ecol. Biogeogr. 21, 1017-1028. https://doi.org/10.1111/j.14668238.2011.00746.x

Lutz, J.A., Furniss, T.J., Johnson, D.J., Davies, S.J., Allen, D., Alonso, A., Anderson-Teixeira, K.J., Andrade, A., Baltzer, J., Becker, K.M.L., Blomdahl, E.M., Bourg, N.A., Bunyavejchewin, S., Burslem, D.F.R.P., Cansler, C.A., Cao, K., Cao, M., Cárdenas, D., Chang, L.W., Chao, K.J., Chao, W.C., Chiang, J.M., Chu, C., Chuyong, G.B., Clay, K., Condit, R., Cordell, S., Dattaraja, H.S., Duque, A., Ewango, C.E.N., Fischer, G.A., Fletcher, C., Freund, J.A., Giardina, C., Germain, S.J., Gilbert, G.S., Hao, Z., Hart, T., Hau, B.C.H., He, F., Hector, A., Howe, R.W., Hsieh, C.F., Hu, Y.H., Hubbell, S.P., InmanNarahari, F.M., Itoh, A., Janík, D., Kassim, A.R., Kenfack, D., Korte, L., Král, K., Larson, A.J., Li, Y. De, Lin, Y., Liu, S., Lum, S., Ma, K., Makana, J.R., Malhi, Y., McMahon, S.M., McShea, W.J., Memiaghe, H.R., Mi, X., Morecroft, M., Musili, P.M., Myers, J.A., Novotny, V., de Oliveira, A., Ong, P., Orwig, D.A., Ostertag, R., Parker, G.G., Patankar, R., Phillips, R.P., Reynolds, G., Sack, L., Song, G.Z.M., Su, S.H., Sukumar, R., Sun, I.F., Suresh, H.S., Swanson, M.E., Tan, S., Thomas, D.W., Thompson, J., Uriarte, M., Valencia, R., Vicentini, A., Vrška, T., Wang, X., Weiblen, G.D., Wolf, A., Wu, S.H., Xu, H., Yamakura, T., Yap, S., Zimmerman, J.K., 2018. Global importance of large-diameter trees. Glob. Ecol. Biogeogr. 27, 849-864. https://doi.org/10.1111/geb.12747

Lutz, J.A., Larson, A.J., Freund, J.A., Swanson, M.E., Bible, K.J., 2013. The importance of large-diameter trees to forest structural heterogeneity. PLoS One 8. https://doi.org/10.1371/journal.pone.0082784 
1268 Maréchaux, I., Chave, J., 2017. An individual-based forest model to jointly simulate carbon and tree diversity in Amazonia: description and applications. Ecol. Monogr. 87, 632-664. https://doi.org/10.1002/ecm.1271

Mascaro, J., Detto, M., Asner, G.P., Muller-Landau, H.C., 2011. Evaluating uncertainty in mapping forest carbon with airborne LiDAR. Remote Sens. Environ. 115, 37703774. https://doi.org/10.1016/j.rse.2011.07.019

Malhi, Y., Adu-Bredu, S., Asare, R.A., Lewis, S.L., Mayaux, P., 2013. African rainforests: Past, present and future. Philos. Trans. R. Soc. B Biol. Sci. https://doi.org/10.1098/rstb.2012.0312

Memiaghe, H.R., Lutz, J.A., Korte, L., Alonso, A., Kenfack, D., 2016. Ecological Importance of Small-Diameter Trees to the Structure, Diversity and Biomass of a Tropical Evergreen Forest at Rabi, Gabon. PLoS One 11. https://doi.org/10.1371/journal.pone.0154988

Meyer, V., Saatchi, S., Clark, D.B., Keller, M., Vincent, G., Ferraz, A., Espírito-Santo, F., D’Oliveira, M.V.N., Kaki, D., Chave, J., 2018. Canopy Area of Large Trees Explains Aboveground Biomass Variations across Nine Neotropical Forest Landscapes. Biogeosciences Discuss. 1-38. https://doi.org/10.5194/bg-2017-547

Molto, Q., Hérault, B., Boreux, J.J., Daullet, M., Rousteau, A., Rossi, V., 2014. Predicting tree heights for biomass estimates in tropical forests -A test from French Guiana. Biogeosciences 11, 3121-3130. https://doi.org/10.5194/bg-11-3121-2014

Momo Takoudjou, S., Ploton, P., Sonké, B., Hackenberg, J., Griffon, S., Coligny, F., Kamdem, N.G., Libalah, M., Mofack, G.I.I., Le Moguédec, G., Pélissier, R., Barbier, N., 2017. Using terrestrial laser scanning data to estimate large tropical trees biomass and calibrate allometric models: A comparison with traditional destructive approach. Methods Ecol. Evol. 9, 905-916. https://doi.org/10.1111/2041-210X.12933 
1293

1294

1295

1296

1297

1298

1299

1300

1301

1302

1303

1304

1305

1306

1307

1308

1309

1310

1311

1312

1313

1314

1315

1316

1317

Morsdorf, F., Meier, E., Kötz, B., Itten, K.I., Dobbertin, M., Allgöwer, B., 2004. LIDAR-based geometric reconstruction of boreal type forest stands at single tree level for forest and wildland fire management, in: Remote Sensing of Environment. pp. 353-362. https://doi.org/10.1016/j.rse.2004.05.013

Muller-Landau, H.C., Condit, R.S., Harms, K.E., Marks, C.O., Thomas, S.C., Bunyavejchewin, S., Chuyong, G., Co, L., Davies, S., Foster, R., Gunatilleke, S., Gunatilleke, N., Hart, T., Hubbell, S.P., Itoh, A., Kassim, A.R., Kenfack, D., LaFrankie, J. V., Lagunzad, D., Lee, H.S., Losos, E., Makana, J.R., Ohkubo, T., Samper, C., Sukumar, R., Sun, I.F., Nur Supardi, M.N., Tan, S., Thomas, D., Thompson, J., Valencia, R., Vallejo, M.I., Muñoz, G.V., Yamakura, T., Zimmerman, J.K., Dattaraja, H.S., Esufali, S., Hall, P., He, F., Hernandez, C., Kiratiprayoon, S., Suresh, H.S., Wills, C., Ashton, P., 2006. Comparing tropical forest tree size distributions with the predictions of metabolic ecology and equilibrium models. Ecol. Lett. 9, 589-602. https://doi.org/10.1111/j.14610248.2006.00915.x

Næsset, E., 2002. Predicting forest stand characteristics with airborne scanning laser using a practical two-stage procedure and field data. Remote Sens. Environ. 80, 8899. https://doi.org/10.1016/S0034-4257(01)00290-5

Newnham, G.J., Armston, J.D., Calders, K., Disney, M.I., Lovell, J.L., Schaaf, C.B., Strahler, A.H., Mark Danson, F., 2015. Terrestrial laser scanning for plot-scale forest measurement. Curr. For. Reports 1, 239-251. https://doi.org/10.1007/s40725015-0025-5

Niklas, K.J., 1994. Plant allometry: the scaling of form and process. University of Chicago Press.

Niklas, K.J., 2007. Maximum plant height and the biophysical factors that limit it, in: Tree Physiology. pp. 433-440. https://doi.org/10.1093/treephys/27.3.433 
1318 Niklas, K.J., Midgley, J.J., Enquist, B.J., 2003. A general model for mass-growth-density 1319 relations across tree-dominated communities. Evol. Ecol. Res. 5, 459-468.

1320 Nobre, C.A., Sampaio, G., Borma, L.S., Castilla-Rubio, J.C., Silva, J.S., Cardoso, M., 2016.

1321 Land-use and climate change risks in the amazon and the need of a novel sustainable development paradigm. Proc. Natl. Acad. Sci. U. S. A. 113, 10759-10768. https://doi.org/10.1073/pnas.1605516113

1324 Nunes, M., Prangle, D., 2015. abctools : An R Package for Tuning Approximate Bayesian 1325 Computation Analyses. R J. 7, 1-16.

1326 Oldeman, R., 1974. The architecture of the forest of French Guiana. L'architecture de la foret Guyanaise, Memoires-ORSTOM. ORSTOM.

1328 Palace, M.W., Sullivan, F.B., Ducey, M.J., Treuhaft, R.N., Herrick, C., Shimbo, J.Z., Mota-ESilva, J., 2015. Estimating forest structure in a tropical forest using field measurements, a synthetic model and discrete return lidar data. Remote Sens. Environ. 161, 1-11. https://doi.org/10.1016/j.rse.2015.01.020

1332 Pan, Y., Birdsey, R.A., Fang, J., Houghton, R., Kauppi, P.E., Kurz, W.A., Phillips, O.L., Shvidenko, A., Lewis, S.L., Canadell, J.G., Ciais, P., Jackson, R.B., Pacala, S.W., McGuire, 1334 A.D., Piao, S., Rautiainen, A., Sitch, S., Hayes, D., 2011. A Large and Persistent Carbon Sink in the World's Forests. Science (80-. ). 333, 988 LP - 993. https://doi.org/10.1126/science.1201609

Pan, Y., Birdsey, R.A., Phillips, O.L., Jackson, R.B., 2013. The Structure, Distribution, and Biomass of the World's Forests. Annu. Rev. Ecol. Evol. Syst. 44, 593-622.

1340 Poncy, O., Sabatier, D., Prévost, M.F., Hardy, I., 2001. The Lowland High Rainforest: 1341 Structure and Tree Species Diversity, in: Bongers, F., Charles-Dominique, P., Forget, 1342 P.M., Théry, M. (Eds.), Nouragues. Monographiae Biologicae, Vol 80. Springer, 
Dordrecht, pp. 31-46.

1344 Poorter, L., Bongers, L., Bongers, F., 2006. Architecture of 54 moist-forest tree species:

1345 Traits, trade-offs, and functional groups. Ecology 87, 1289-1301.

1346 Pretzsch, H., 2014. Canopy space filling and tree crown morphology in mixed-species

1347 stands compared with monocultures. For. Ecol. Manage. 327, 251-264. https://doi.org/10.1016/j.foreco.2014.04.027

1349 Pretzsch, H., Dieler, J., 2012. Evidence of variant intra- and interspecific scaling of tree crown structure and relevance for allometric theory. Oecologia 169, 637-649. https://doi.org/10.1007/s00442-011-2240-5

Purves, D.W., Lichstein, J.W., Strigul, N., Pacala, S.W., 2008. Predicting and understanding forest dynamics using a simple tractable model. Proc. Natl. Acad. Sci. 105, 1701817022. https://doi.org/10.1073/pnas.0807754105

Pyörälä, J., Saarinen, N., Kankare, V., Coops, N.C., Liang, X., Wang, Y., Holopainen, M., Hyyppä, J., Vastaranta, M., 2019. Variability of wood properties using airborne and

R Development Core Team, 2019. R: A Language and Environment for Statistical terrestrial laser scanning. Remote Sens. Environ. 235. Computing. R Found. Stat. Comput. https://doi.org/10.1007/978-3-540-74686-7

Réjou-Méchain, M., Muller-Landau, H.C., Detto, M., Thomas, S.C., Le Toan, T., Saatchi, S.S., Barreto-Silva, J.S., Bourg, N.A., Bunyavejchewin, S., Butt, N., Brockelman, W.Y., Cao, M., Cárdenas, D., Chiang, J.M., Chuyong, G.B., Clay, K., Condit, R., Dattaraja, H.S., Davies, S.J., Duque, A., Esufali, S., Ewango, C., Fernando, R.H.S., Fletcher, C.D., N. Gunatilleke, I.A.U., Hao, Z., Harms, K.E., Hart, T.B., Hérault, B., Howe, R.W., Hubbell, S.P., Johnson, D.J., Kenfack, D., Larson, A.J., Lin, L., Lin, Y., Lutz, J.A., Makana, J.R., Malhi, Y., Marthews, T.R., Mcewan, R.W., Mcmahon, S.M., Mcshea, W.J., Muscarella, 

Suresh, H.S., Suwanvecho, U., Thomas, D.W., Thompson, J., Uríarte, M., Valencia, R., Vicentini, A., Wolf, A.T., Yap, S., Yuan, Z., Zartman, C.E., Zimmerman, J.K., Chave, J., 2014. Local spatial structure of forest biomass and its consequences for remote sensing of carbon stocks. Biogeosciences 11, 6827-6840. https://doi.org/10.5194/bg-11-6827-2014

Réjou-Méchain, M., Tanguy, A., Piponiot, C., Chave, J., Hérault, B., 2017. Biomass: an R Package for Estimating Above-Ground Biomass and Its Uncertainty in Tropical Forests. Methods Ecol. Evol. 8, 1163-1167. https://doi.org/10.1111/2041210X.12753

Réjou-Méchain, M., Tymen, B., Blanc, L., Fauset, S., Feldpausch, T.R., Monteagudo, A., Phillips, O.L., Richard, H., Chave, J., 2015. Using repeated small-footprint LiDAR

Riaño, D., Valladares, F., Condés, S., Chuvieco, E., 2004. Estimation of leaf area index and covered ground from airborne laser scanner (Lidar) in two contrasting forests. acquisitions to infer spatial and temporal variations of a high-biomass Neotropical forest. Remote Sens. Environ. 169, 93-101. https://doi.org/10.1016/j.rse.2015.08.001 retrieval. Int. J. Comput. Vis. 40, 99-121. 
https://doi.org/10.1023/A:1026543900054

1394

1395

1396

1397

1398

1399

1400

1401

1402

1403

1404

1405

1406

1407

1408

1409

1410

1411

1412

1413

1414

1415

1416

1417

Schimel, D., Pavlick, R., Fisher, J.B., Asner, G.P., Saatchi, S., Townsend, P., Miller, C., Frankenberg, C., Hibbard, K., Cox, P., 2015. Observing terrestrial ecosystems and the carbon cycle from space. Glob. Chang. Biol. https://doi.org/10.1111/gcb.12822

Seidl, R., Rammer, W., Spies, T.A., 2014. Disturbance legacies increase the resilience of forest ecosystem structure, composition, and functioning. Ecol. Appl. 24, 20632077. https://doi.org/10.1890/14-0255.1

Shugart, H.H., Asner, G.P., Fischer, R., Huth, A., Knapp, N., Le Toan, T., Shuman, J.K., 2015. Computer and remote-sensing infrastructure to enhance large-scale testing of individual-based forest models. Front. Ecol. Environ. 13, 503-511. https://doi.org/10.1890/140327

Shugart, H.H., Saatchi, S., Hall, F.G., 2010. Importance of structure and its measurement in quantifying function of forest ecosystems. J. Geophys. Res. Biogeosciences 115, G2. https://doi.org/10.1029/2009JG000993

Spriggs, R.A., Vanderwel, M.C., Jones, T.A., Caspersen, J.P., Coomes, D.A., 2019. A critique of general allometry-inspired models for estimating forest carbon density from airborne LiDAR. PLoS One 14, e0215238. https://doi.org/10.1371/journal.pone.0215238

Spriggs, R.A., Vanderwel, M.C., Jones, T.A., Caspersen, J.P., Coomes, D.A., 2015. A simple area-based model for predicting airborne LiDAR first returns from stem diameter distributions: An example study in an uneven-aged, mixed temperate forest. Can. J. For. Res. 45, 1338-1350. https://doi.org/10.1139/cjfr-2015-0018

Sterck, F.J., Bongers, F., 2001. Crown development in tropical rain forest trees: Patterns with tree height and light availability. J. Ecol. 89, 1-13. https://doi.org/10.1046/j.1365-2745.2001.00525.x 
Stovall, A.E.L., Anderson-Teixeira, K.J., Shugart, H.H., 2018. Assessing terrestrial laser scanning for developing non-destructive biomass allometry. For. Ecol. Manage. 427, 217-229. https://doi.org/10.1016/j.foreco.2018.06.004

Stovall, A.E.L., Shugart, H., Yang, X., 2019. Tree height explains mortality risk during an intense drought. Nat. Commun. 10. https://doi.org/10.1038/s41467-019-12380-6

Strigul, N., Pristinski, D., Purves, D., Dushoff, J., Pacala, S., 2008. Scaling from trees to forests: Tractable macroscopic equations for forest dynamics. Ecol. Monogr. 78, 523-545. https://doi.org/10.1890/08-0082.1

Sullivan, M.J.P., Lewis, S.L., , W., Qie, L., Baker, T.R., Banin, L.F., Chave, J., Cuni-Sanchez, A., Feldpausch, T.R., Lopez-Gonzalez, G., Arets, E., Ashton, P., Bastin, J.F., Berry, N.J., Bogaert, J., Boot, R., Brearley, F.Q., Brienen, R., Burslem, D.F.R.P., de Canniere, C., Chudomelová, M., Dančák, M., Ewango, C., Hédl, R., Lloyd, J., Makana, J.R., Malhi, Y., Marimon, B.S., Junior, B.H.M., Metali, F., Moore, S., Nagy, L., Vargas, P.N., Pendry, C.A., Ramírez-Angulo, H., Reitsma, J., Rutishauser, E., Salim, K.A., Sonké, B., Sukri, R.S., Sunderland, T., Svátek, M., Umunay, P.M., Martinez, R.V., Vernimmen, R.R.E., Torre, E.V., Vleminckx, J., Vos, V., Phillips, O.L., 2018. Field methods for sampling tree height for tropical forest biomass estimation. Methods Ecol. Evol. 9, 1179-1189. https://doi.org/10.1111/2041-210X.12962

Swain, M.J., Ballard, D.H., 1991. Color indexing. Int. J. Comput. Vis. 7, 11-32. https://doi.org/10.1007/BF00130487

Tanskanen, H., Venäläinen, A., Puttonen, P., Granström, A., 2005. Impact of stand structure on surface fire ignition potential in Picea abies and Pinus sylvestris forests in southern Finland. Can. J. For. Res. 35, 410-420. https://doi.org/10.1139/x04-188

Taubert, F., Jahn, M.W., Dobner, H.-J., Wiegand, T., Huth, A., 2015. The structure of 
tropical forests and sphere packings. Proc. Natl. Acad. Sci. 112, 15125-15129. https://doi.org/10.1073/pnas.1513417112

Tebaldini, S., Ho Tong Minh, D., Mariotti d'Alessandro, M., Villard, L., Le Toan, T., Chave, J., 2019. The Status of Technologies to Measure Forest Biomass and Structural Properties: State of the Art in SAR Tomography of Tropical Forests. Surv. Geophys.

Ter Steege, H., Pitman, N.C.A., Phillips, O.L., Chave, J., Sabatier, D., Duque, A., Molino, J.F., Prévost, M.F., Spichiger, R., Castellanos, H., Von Hildebrand, P., Vásquez, R., 2006. Continental-scale patterns of canopy tree composition and function across Amazonia. Nature 443, 444-447. https://doi.org/10.1038/nature05134

Thomas, S.C., 1996. Asymptotic height as a predictor of growth and allometric characteristics in Malaysian rain forest trees. Am. J. Bot. 83, 556-566. https://doi.org/10.2307/2445913

Vaglio Laurin, G., Chen, Q., Lindsell, J.A., Coomes, D.A., Frate, F. Del, Guerriero, L., Pirotti, F., Valentini, R., 2014. Above ground biomass estimation in an African tropical forest with lidar and hyperspectral data. ISPRS J. Photogramm. Remote Sens. 89,

1464 Vincent, G., Antin, C., Laurans, M., Heurtebize, J., Durrieu, S., Lavalley, C., Dauzat, J., 2017. 1465 Mapping plant area index of tropical evergreen forest by airborne laser scanning. A 49-58. https://doi.org/10.1016/j.isprsjprs.2014.01.001

Van Leeuwen, M., Hilker, T., Coops, N.C., Frazer, G., Wulder, M.A., Newnham, G.J., Culvenor, D.S., 2011. Assessment of standing wood and fiber quality using ground and airborne laser scanning: A review. For. Ecol. Manage. cross-validation study using LAI2200 optical sensor. Remote Sens. Environ. 198, 254-266. https://doi.org/10.1016/j.rse.2017.05.034 
1468 West, G.B., Brown, J.H., Enquist, B.J., 1999. A general model for the structure and 1469 allometry of plant vascular systems. Nature 400, 664-667.

$1470 \quad$ https://doi.org/10.1038/23251

1471 West, G.B., Enquist, B.J., Brown, J.H., 2009. A general quantitative theory of forest

1472 structure and dynamics. Proc. Natl. Acad. Sci. U. S. A. 106, 7040-7045.

1473 https://doi.org/10.1073/pnas.0812294106

1474 Wickham, H., 2011. ggplot2. Wiley Interdiscip. Rev. Comput. Stat.

1475 https://doi.org/10.1002/wics.147

1476 Zanne, A.E., Lopez-Gonzalez, G., Coomes, D.A., Ilic, J., Jansen, S., Lewis, S.L., Miller, R.B.,

1477 Swenson, N.G., Wiemann, M.C., Chave, J., 2009. Data from: Global wood density

1478 database. Dryad Digit. Repos. https://doi.org/10.5061/dryad.234

1479 Zolkos, S.G., Goetz, S.J., Dubayah, R., 2013. A meta-analysis of terrestrial aboveground 1480 biomass estimation using lidar remote sensing. Remote Sens. Environ. 128, 2891481 298. https://doi.org/10.1016/j.rse.2012.10.017 
1483

1484

1485

1486

1487

1488

1489

1490

1491

1492

1493

1494

1495

1496

1497

1498

1499

1500

1501

1502

1503

1504

1505

1506

1507

\section{List of Figure Captions}

Figure 1: The two-step procedure of the Canopy Constructor algorithm. Step 1 uses tree inventory data, and a canopy height model (CHM). To infer the position and size of each tree, the algorithm creates an initial reconstruction drawing randomly dimensions from allometric relationships between tree dimensions. In ill-fitting regions (red), deviations from the allometric means are swapped between trees until a good spatial fit is obtained (green). Step 2 extrapolates the results of step 1 and creates virtual inventories across thousands of hectares, following the same fitting algorithm as in step 1, but with fitted trees drawn from a distribution (see main text for details).

\section{Figure 2: Example of canopy reconstruction at the Petit Plateau plot, Nouragues.}

Shown are the initial canopy height model (CHM) where tree dimensions are randomly drawn from site-specific allometries (a), the ALS-derived CHM (b), and the final reconstruction of the Canopy Constructor (c).

\section{Figure 3: Inferred allometries at Nouragues and Rabi (step 1). The panels show} height allometries (top row) and crown allometries (bottom row), as inferred by the Canopy Constructor, for Nouragues (a,d), Rabi (b,e) and both sites combined (c,f). The grey background indicates the prior range. Mean and 75\% highest density intervals are given for each plot separately, i.e. for Grand Plateau (orange) and Petit Plateau (dark red) at Nouragues, and for the 10 ha (light blue) and 15ha (dark blue) plot at Rabi. As comparison, we have plotted empirical height allometries measured from in the field for both Grand Plateau (dotted) and Petit Plateau (dashed) in the top panels, as well as a single ground-inferred allometry at Rabi (dotted). Results for same inference procedure, but with a lower number of simulation runs, are provided in Figure S8. 
Figure 4: Aboveground biomass predictions for ALS campaign at Nouragues and

1510 Rabi (step 2). Maps show the mean aboveground biomass values ( $\mathrm{t}$ ha-1) predicted

1511 with the Canopy Constructor approach across 2,016 ha at Nouragues (panel a) and 832

1512 ha at Rabi (panel d), as well as the respective coefficient of variation across 100

1513 simulations (panels b and e, dimensionless). Also given are the overall distributions of

1514 aboveground biomass (panels $\mathrm{c}$ and $\mathrm{f}$, red distributions, in t ha-1) and previously

1515 obtained estimates (panels $\mathrm{c}$ and $\mathrm{f}$, yellow) from a pooled regression-model (Labrière et

1516 al. 2018). Clearly evident is the shrinkage towards the mean in the regression-based

1517 approach, as opposed to much stronger variation in the Canopy Constructor approach.

1518 Please note that the geographic extent of the maps has been rescaled for visualization

1519 purposes.

1520

1521 Figure 5: Evaluation of aboveground biomass predictions in extrapolation (step

1522 2). Shown are the predictions of aboveground biomass (median of 100 posterior

1523 simulations, given in $\left.\mathrm{t} \mathrm{ha}^{-1}\right)$ at the 1 ha scale $(\mathrm{a}, \mathrm{b})$ and 0.25 ha scale $(\mathrm{c}, \mathrm{d})$. The left

1524 column shows the results when the space-filling approach is applied the calibration

1525 plot from which allometries and packing densities were derived ("Model fit"), the right

1526 column the results when the approach is transferred between plots ("Cross-

1527 validation"). The Nouragues results are plotted in red/orange, and for Rabi in dark/light

1528 green. Goodness of fit values are provided in the bottom-right corner of the panels. MBE

1529 does not change between 0.25 and 1 ha scales and is thus only given in the top panels.

1530 For visualization purposes, we only plot error bars at the hectare scale, representing the

1531 interquartile ranges of estimates from 100 posterior simulations. 